\title{
Assessment of Landscape Co-Benefits in Natura 2000 Site Management Plans
}

\author{
Maria Rosa Trovato ${ }^{1, *(D)}$, Paolo Micalizzi ${ }^{2}$ and Salvatore Giuffrida ${ }^{1, *(D)}$ \\ 1 Department of Civil Engineering and Architecture, University of Catania, 95125 Catania, Italy \\ 2 Freelancer, 95024 Acireale, Italy; paolomicas@gmail.com \\ * Correspondence: mrtrovato@dica.unict.it (M.R.T.); salvatore.giuffrida@unict.it (S.G.); \\ Tel.: +39-377-4593036 (M.R.T.); +39-335-7995263 (S.G.)
}

Citation: Trovato, M.R.; Micalizzi, P.;

Giuffrida, S. Assessment of

Landscape Co-Benefits in Natura 2000 Site Management Plans.

Sustainability 2021, 13, 5707. https://

doi.org/10.3390/su13105707

Academic Editor: Francesca

Abastante

Received: 26 March 2021

Accepted: 11 May 2021

Published: 19 May 2021

Publisher's Note: MDPI stays neutral with regard to jurisdictional claims in published maps and institutional affiliations.

\begin{abstract}
The concept of co-benefits developed in the context of climate change policies can be extended to the strategies aimed at protecting natural resources. A co-effects-based policy approach proposes a multidimensionality capable of strengthening its effectiveness and supporting a cogenerative development model aimed at promoting virtuous forms of territorial capital valorisation. The study aimed to evaluate the landscape co-benefits generated by the Natura 2000 networks, achieving a measure of efficiency of the policies and performance of the Management Plan, with reference to the "Timpa di Acireale" site. CVM and TCM were used for the estimation of landscape co-benefits. For the evaluation of the efficiency of the policies and the performance of the Plan, some economic-financial criteria were implemented. With reference to the user-citizen, the local tourist and the supralocal tourist, flows of annual co-benefits of EUR 754,764, EUR 99,678.12 and EUR 2276.39, respectively, were estimated. The analyses of the efficiency of the policies and the performance of the Plan provided sufficient results. In conclusion, the lack of an adequate level of infrastructure for all users' profiles reduces the ability to generate co-benefits for the users themselves and more significantly for tourists in a territory with a strong tourism vocation.
\end{abstract}

Keywords: externalities; policies for the protection of natural resources; management plan; contingent valuation method; travel cost

\section{Introduction}

Early studies on the idea of co-benefits claimed that policies to control GHG generate additional benefits for society [1]. In the early 1990s, many authors incorporated the indirect and secondary benefits of air pollution control into cost-benefit analyses; although they did not use proper terminology yet, they referred to the concept of co-benefits $[2,3]$. These studies used the concept of co-benefits in line with the "co-impact" category to study air pollution in Europe. An analysis of the definition of co-benefits presented in the IPCC reports revealed that this term was developed from the "ancillary benefits" term. The ancillary benefits were first introduced in the second IPCC report 2001, in which co-benefits were not mentioned yet [4]. In the third report of the 2001 IPCC, [5] the two terms are both present and distinct, and reference is made to collateral benefits specific to climate change policy (ancillary benefits) and to collateral benefits of any policy (co-benefits). This distinction is missing in the subsequent 2007 IPCC report [6], while the 2014 report introduces the same definition for both terms [7].

The success of the co-beneficial approach consolidation can be explained by its "defence potentials" in relation to climate change. A key climate change policy problem is that it is a "bad" issue, as the benefits of climate policy are only visible in the long term, cannot be causally related and may be more important in some parts of the world, while the costs of action are immediate, high and are paid by specific actors. The concept of co-benefits has "defence potentials" as a co-benefit strategy helps align the time gap and scale between the costs and the benefits/impacts of climate policy by offsetting other co-benefits that are 
often local, have immediate effect and are easier to measure and therefore more politically feasible to scale. The recognition of co-benefits thus opens a "window of opportunity" for the achievement of certain policy objectives as side effects of another objective that might be at a higher level in the current political agenda. In addition, co-benefits can take the form of social benefits and thus legitimize the political action of governments in the public sector.

The purpose of the co-benefit approach is to maximise the expected impacts of a policy or intervention (e.g., reduction of greenhouse gases, air pollutants or traffic congestion) to reduce the overall costs to society through the implementation of many sets of objectives in policies and projects. The possibility of maximising development returns on climate change mitigation investments was specifically acknowledged by the International Panel on Climate Change (IPCC) in its most recent evaluation report: "Integrating air pollution abatement and climate change mitigation policies offers potentially significant cost reductions compared to treating such policies in isolation" [8]. The co-benefit approach (i) intentionally internalizes co-benefits to conceive a policy or a project in order to maximize its collateral benefits exceeding its ancillary or secondary benefits, which are random; (ii) takes into account measures involving short-term benefits (called transient benefits) and measures producing GHG reductions and other long-term benefits; and (iii) considers side benefits and trade-offs to ensure that the policy or project to maximise side benefits in a "problem area" has no negative effects causing another problem, or if it does, at least the trade-offs will need to be minimised [9].

Policies to combat climate change can help to achieve objectives that have not been identified beforehand and involve benefits or trade-offs.

The evaluation and systematization of the latter within the general framework of climate strategies can help increase the level of effectiveness and expand its effects to a more inclusive audience of sectors and with a gradation at different scales.

The concept of co-benefits that emerged and developed in the context of climate change policies can be extended to other policies.

The direct objectives pursued by these policies, in fact, involve a series of underlying but indirect objectives, whose effects may extend the benefits or costs generated by them, but above all these effects may highlight and mediate trade-offs implicitly generated, as in most cases there is a lack of awareness or control of the latter between sectors and at different scales.

The objectives and the strategies identified to achieve the secondary effects act as an umbrella for other underlying objectives and other strategies not previously identified which extend and outline a wider range of actions, promoting more inclusive implementation and cross-sector scaling and fostering greater coherence, awareness of the specific policy issue and justification of costs.

In this context, policies aimed at the protection and conservation of natural resources generate underlying and indirect objectives, the pursuit of which may broaden the scope of such policies, inter-linking a plurality of actors and thus promoting a co-generative model of development heralding better systemic communication in the Luhmannian sense and capable of increasing the production of social and territorial capital.

Such policies generate several co-effects (co-benefits or co-costs), the evaluation of which can improve their effectiveness and efficiency and the standard of the trade-offs that are inevitably generated as well.

The policy of the European Union for the conservation of nature and biodiversity has promoted several laws: the Birds Directive whose first version dates back to 1979, then integrated in Directive 2009/147/EC "Birds" providing complete protection to all species of wild birds naturally present in the Union [10]; in 1992, the EU adopted the Directive 92/43/EEC "Habitat" [11] aimed at conserving biodiversity, protecting over 1000 animal and plant species and over 200 habitat types, establishing the EU-wide Natura 2000 network of protected areas, consisting of Sites of Community Interest (SCI), identified by the Member States in accordance with the Habitats Directive, which are subsequently designated as 
Special Areas of Conservation (SAC), and also including the Special Protection Areas (SPA) established under Directive 2009/147/EC "Birds" concerning the conservation of wild birds; in 1999, the EU strengthened the role of zoos for the conservation of biodiversity [12] and, in the wake of the EU Biodiversity Strategy until 2020, committed itself to protecting indigenous biodiversity and ecosystem services against invasive alien species [13]; the EU has introduced specific legislation regulating certain aspects of wildlife trade [14,15] and the techniques of hunting the fauna [16].

The EU has also promoted several initiatives: the EU's biodiversity strategy for 2030 is a comprehensive, ambitious and long-term plan to protect nature and reverse the degradation of ecosystems. The strategy aims to put Europe's biodiversity on a path to recovery by 2030 and contains specific actions and commitments. It is the proposal for the EU's contribution to the upcoming international negotiations on the global post-2020 biodiversity framework. A core part of the European Green Deal [17] will also support a green recovery following the COVID-19 pandemic; on 16 December 2016, the Commission published the "Fitness Check" evaluation of the EU Birds and Habitats Directives (the "Nature Directives") and concluded that, within the framework of broader EU biodiversity policy, they remain highly relevant and are fit for purpose; a roadmap for this initiative was published on 10 February 2017.

In Italy, the policies of protection and conservation of nature and biodiversity, which implement the European legislation, are articulated in marine biodiversity [18-30]; Earth's biodiversity [31-37]; inland water biodiversity; conservation and restoration of ecosystems [38-40]; forest [41-43]; terrestrial protected areas [44-52]; marine protected areas [53-57]; agricultural biodiversity [58]; apiculture [59]; sustainable use of biodiversity [60]; invasive alien species [61]; and wildlife management [62-65].

The policies promoted by the European Union and the Italian government for the conservation of nature and biodiversity are developed through strategies and actions that by promoting virtuous forms of enhancement of natural capital de facto determine appropriately calibrated and interconnected forms of valorisation of social and territorial capital [66-73].

The evaluation of the co-benefits produced by actions to protect and conserve natural capital can supplement and support the effectiveness of territorial policies, in view of their economic inefficiency, implicit in the very concept of the common good and the public good.

The objective of the study in the context of the presented framework was to assess the landscape co-benefits generated by the Natura 2000 networks [11], with reference to the case study of the "Timpa di Acireale" site.

In particular, the study, starting from the monetary evaluation of these co-benefits, continued to a measure of the efficiency of policies for the protection and conservation of natural capital and to a measure of the performance of the Natura 2000 Site Management Plan "Timpa di Acireale" (Figure 1).

Based on an approach aimed at identifying underlying objectives and possible supporting strategies, the aim was not only to ensure the correct implementation of the policy but also a more extensive and comprehensive multidimensionality in terms of subjects, resources and sectors. Such multidimensionality can strengthen the effectiveness of the policy itself and support the choice of those actions that best match the needs of a cogenerative development model, which is able to improve systemic communication and promote virtuous forms of enhancement of natural, social and territorial capital. 
1. Assess the landscape co-benefits generated by the Natura site

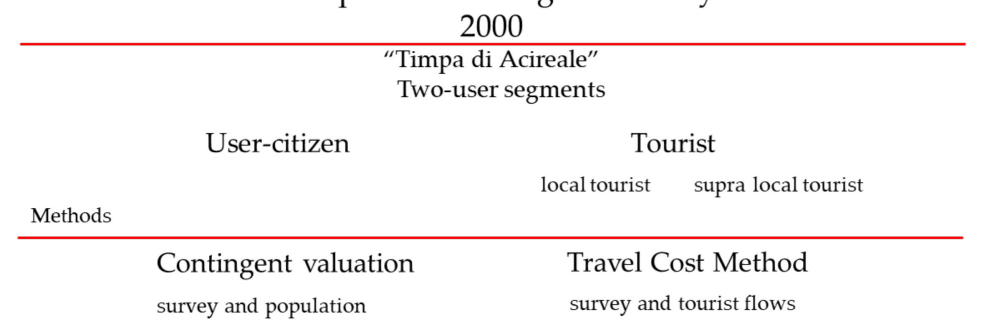

2. Cost-effectiveness of actions to protect the natural heritage

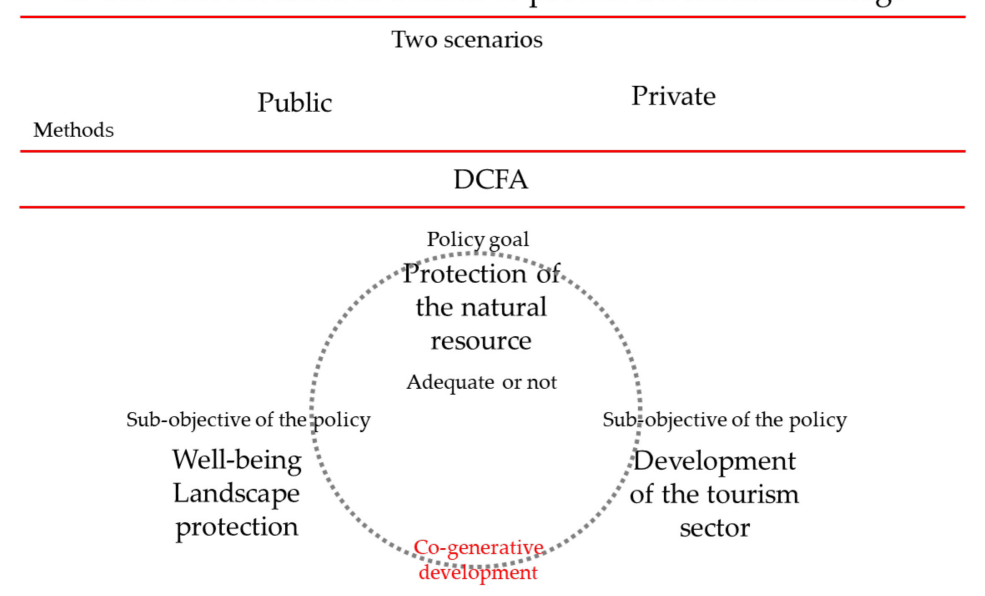

Figure 1. Flowchart-steps of research project.

The Paper Structure

The paper is organized in the following sections:

Section 3 presents the theoretical and methodological approach to the monetary evaluation of landscape co-benefits.

Section 4 introduces the case study of Natura 2000 "La Timpa di Acireale" site.

Section 5 reports and discusses the results.

Section 6 proposes some reflections on the extension of the concept of co-benefits that emerged and developed in the context of climate change policies and was promoted by the IPCC to include the protection and conservation of natural resources.

Section 7 proposes a synthesis of the results and identifies the lines of future development of this research.

Appendix A highlights the general objectives of the Management Plan of the Natura 2000 "Timpa di Acireale" site, which aim at the conservation of habitats, species and environmental resources.

Appendix B highlights the management actions identified in the Management Plan of the Natura 2000 "Timpa di Acireale" site, grouped into different categories based on the nature and general objective which they pursue.

Appendix $C$ highlights the estimated costs of the actions set out in the Management Plan.

\section{A Literature Review on Economic Benefits of the Natura 2000 Network}

The Natura 2000 network consists of 26,400 sites and covers almost $18 \%$ of the EU territory. The network is a central element of the EU's wider green infrastructure, which together make up a large part of living natural capital.

In recent years there has been an increasing, complementary interest in and recognition of the socio-economic benefits of biodiversity [74-76] and from protected areas [77-81].

In addition to its biodiversity benefits, the Natura 2000 network provides a range of benefits to society and the economy via the flow of ecosystem services (provisioning, regulating, cultural and supporting services). 
Natural hazard benefits and climate adaptation: mitigating the damaging impacts of natural disasters [75,76]. In particular, protected areas are recognized to maintain healthy, intact and robust ecosystems, which help mitigate the impacts of disasters and restore destroyed or degraded areas [82]. Protected areas play an important role as well in decreasing the vulnerability of communities to disasters and reducing their physical exposure to natural hazards, often providing them with livelihood resources to withstand and recover from crises. In general, ecosystems affect both the probability and severity of extreme events, and they can moderate their effects. Natural hazards have caused significant damage across the EU over time. Around 15 million people in Europe have been affected over the period with an associated cost estimated at around EUR 163 billion. This equates to an annual average damage of EUR 7 billion/year [83].

Tourism and recreation benefits: the benefits are provided by tourism and recreation (i.e., market on non-market benefits) and refer to use values and the direct and indirect employment supported by the Natura 2000 network [84]; the value of recreational visits to Natura 2000 sites is EUR 5-9 billion per annum, based on estimates of visitors' willingness to pay; the total expenditure related to tourism and recreation supported by Natura 2000 was between around EUR 50 and EUR 85 billion in 2006; the expenditure exclusively related to the visitors who have an affinity for Natura 2000 sites (i.e., around $21 \%$ of visitors to Natura 2000) was between EUR 9 and EUR 20 billion in 2006, generated by around 350 million visitor days; the total expenditure provided by tourism and recreation supports between 4.5 and 8 million Full-Time Employment (FTE) jobs [83]. The benefits generated by the visitors with affinity to Natura 2000 would support from 800,000 to 2 million FTE jobs. Natura 2000 sites supported on average about 12 million FTE jobs each year in the EU during the period 2006-2008. This includes about 1.5 million jobs in agriculture, 70,000 jobs in forestry, around 200,000 jobs in fishing, 3.1 million jobs in recreation (excluding employment generated by hotels and restaurants) and 7 million jobs in other industries.

Water purification and supply benefits (and waste): water purification and provision are important ecosystem services that are provided by natural ecosystems, including protected areas such as Natura 2000. The natural water purification and its supply, offering significant savings over man-made substitutes. The annual economic benefits of water purification are between EUR 7 and EUR 16 million and of water provision between EUR 12 and EUR 91 million per the European cities [83].

Marine protected areas and fish, and terrestrial protected areas, pollination and agriculture:

(a) Food security and provision-Marine Protected Areas-Fisheries: The influence of marine protected areas on fisheries is a controversial issue. Natura 2000 management measures may lead to a reduction and/or a change in fishing activity. It will be reduced in the short term but may benefit from neighbouring areas with more fish in the long term.

(b) Food security and provision-Terrestrial Protected Areas-Pollination: Pollination represents an essential ecosystem service for human well-being, being a key ecological process on which natural and agricultural systems depend [75-85]. It is estimated that insect pollinators are directly responsible for $9.5 \%$ (around EUR 153 billion) of the total value of the world's agricultural food production in 2005 [86].

(c) Food security and provision-Terrestrial Protected Areas-Agriculture: while agroecosystems directly contribute to the provision of food for human consumption through supporting the world's agriculture, the biodiversity and ecosystems contribute to them in an indirect way. The organic agriculture represents a promising agricultural management option for some Natura 2000 sites and protected areas under agricultural land use. From the current available data, it is difficult to estimate the portion of agricultural output directly attributable to the Natura 2000 network. The biodiversity benefits to agriculture through ecosystem services are provisioning, regulating, supporting and cultural. 
Health, identity and learning: the role of ecosystems in supporting human health is manifold: natural ecosystems are known to play an important role in supporting physical and mental health by providing possibilities for outdoor activities, recreation and relaxation; the ecosystems play a positive role in protecting human health through the mitigation of natural hazards and particularly by maintaining air quality; naturally functioning ecosystems can regulate the range and number of species that are dangerous to human health; Gantioler et al. [81] evinced the role of Natura 2000 in preserving genetic and species diversity, but the value of actual benefits gained from using sites for food, fibre, medicines and pharmaceuticals is currently low [83].

Researchers have produced several studies aimed at the monetary measurement of the benefits of Natura 2000 sites.

In 2014, Lower Danube Green Corridor restoration contributed to the restoration of floodplains and ensure flood protection in the region (Bulgaria, Romania, Moldova and Ukraine). The 2005 Danube flood had resulted in EUR 396 million in damages. Benefits have been provided through flood alleviation services [87].

A LIFE project (2001-2005) [88] called Theiss has proposed the management of floodplains on the Tisza reintroducing environmentally friendly land-use practices in the Natura 2000 site in the Nagykörü-Tóalj, Tiszakürt and Tiszajenő sites, Hungary (Austria and Hungary). In this project, the infrastructures have been improved and new reservoirs were developed to restore the water bodies (about $96 \mathrm{ha}$ ) and improve grassland habitats (290 ha). In addition, sustainable grazing and meadow management was implemented, creating 10 permanent jobs for farmers.

In 2010, the Copernicus Science Centre, located in the city centre of Warsaw (Poland), opened a green rooftop garden to contribute to the conservation of the Natura 2000 area [89]. The new habitat provides many services such as a place for recreation and relaxation and a home for insects and birds. During winter, the rooftop isolates from the cold and in summer it prevents the building from overheating.

A LIFE+ project called Land of the Bison promoted the protection of the European bison and implemented an ecosystem approach management in the most ecologically valuable forest in Poland. Local households can use wild berries, mushrooms and nuts for around EUR 250,000 in selling it to the food processing industry and firewood to heat their home. The local honey that has the "Białowieski lipiec" label is a high-quality product that provides regular revenue to the local population. The natural herbs, fungi and wild berries are processed into medicines by the Polish company Herbapol contributing to the support of local economy. The protection of biodiversity secures the water supply service for domestic, business and recreational use. The Natura 2000 site hosting outdoor activities such as walking, bird watching, biking and canoeing increases the tourist flow for each year. The site offers work to 110 units. The forest provides timber for EUR 6,000,000 per year, and over $80 \%$ of the wood is sold outside of the region [90].

The Igniş Natura 2000 site (North West Carpathians, Romania) offers many goods to the local population such as food, firewood and natural medicines. The site also provides drinking water for two-thirds of the population of the municipality of Baia Mare [91]. Fifty per cent of the forest at the site ensures watershed, soil and climate protection as well as recreation services. Sustainable management of the region thus contributes to the maintenance of high-quality drinking water and a viable environment.

A LIFE project (2010-2013) called Saving Transylvania's Important Pastoral Ecosystems (STIPA) [92] aimed to improve the conservation status of dry grassland habitats in Sighișoara-Târnava Mare, Romania. The project successfully implemented a model of sustainable grassland management in one of the largest high-nature-value lowland areas in the European Union. The plan provides sustainable livelihoods in rural areas and economic growth. Winner of the 2015 Socio-Economic Benefits Award, the Romanian project generated EUR 2,5 million annual benefits, increasing the incomes of 2300 farming families.

The POLPROPNATURA project aimed at creating tourism products and a marketing strategy to promote Natura 2000 benefits (North Latvia). The project supported sustainable 
management of the site, generating long-term socio-economic benefits for the park. The measures introduced have increased the tourist flows, and in 2011, visitors spent around EUR 1 million in the park. The number of companies providing travel services also rose from 23 to 48 after the project, ensuring additional workplaces.

In West Hungary, the Natura 2000 site of Lake Hévíz ensures strong protection of Europe's largest thermal and medicinal source waters. Hungary is the fifth-highest health and medical destination in the world, and this unique area offers natural treatment of rheumatic and other health problems to international and local visitors. It has been estimated that Hévíz tourists spend twice as much as visitors in other tourist destinations in Hungary.

In Eastern Poland, a network of Nordic walking trails was established in Hajnówka. This initiative provides mutual benefits to the local rural community and nature at the heart of the Białowieża Natura 2000 forest. The tourism benefits account for EUR 100,000 paid in entrance fees per year. The area also promotes health through outdoor physical activities (such as cycling, biking and canoeing) and raises environmental awareness [93].

The recognition and demonstration of the wider socio-economic benefits of Natura 2000 can influence stakeholder attitudes and support for the Natura 2000 network, attract funding for conservation measures and other investment in and around sites, inform land-use (change) decisions and help in the integration of protected areas in regional development planning and practice.

Designation of areas valuable for biodiversity as Natura 2000 sites does not automatically guarantee that their favourable conservation status is maintained or restored. While designation is a valuable first step, appropriate management and restoration of Natura 2000 sites is needed to ensure that the conservation objectives and related socio-economic co-benefits are reached in practice. This requires sufficient financial resources, capacity to carry out management activities in an effective manner and continued support from both stakeholders and decision-makers alike [86].

\section{Methods}

An extension of the concept of co-benefits to the context of policies aimed at the protection of natural capital extends the operational dimension of such policies, insofar as they may give rise to a plurality of objectives underlying and indirect to the general one. The identification and systematization of these objectives are instrumental in integrating these policies with those aimed at supporting the development of all territorial resources, thus increasing the capacity for communication between social systems and promoting a form of co-generative capable of promoting processes that lead to increases in share capital. The identification of underlying objectives enhances and promotes the overall objective. In fact, the underlying objectives can be identified as specific objectives of the general one. Similarly, strategies aimed at pursuing these specific objectives can be identified as being underlying the overall strategy.

The actions promoted by the underlying strategies as specific actions of those of protection and conservation of the natural heritage.

This process of systematization and hierarchization of objectives, strategies and actions helps to correlate resources, sectors and subjects in a process capable of producing coordinated development. The effects produced on the different territorial components by these policies must be integrated into their specific development objectives, enhancing the co-benefits and mediating the trade-offs generated. The latter, in fact, represent a crucial point for the coordination of the different territorial components and for systemic communication. The process of identifying co-benefits produced by natural capital protection policies can be supported by the definition of ecosystem services provided by the Millennium Ecosystem Assessment (MA) [76].

With reference to the specific objective of this study aimed at detecting and assessing the landscape co-benefits generated by the Natura 2000 networks, the ecosystem 
services offered by the natural resource are those which relate to cultural values and to recreational values.

The general objective of resource-specific protection opens up a range of potential instrumental opportunities to develop the economic sector and increase social well-being by interlinking natural, economic and social sub-systems.

The protection action, while on the one hand, becoming the prerequisite for increasing social welfare and developing the tourist-recreational system, on the other hand, determines a series of trade-offs between the need for protection which imposes a constraining regime with regard to the destinations of use, localisation and development of other activities.

The framework of the arrangements resulting from these mediation processes, if on the one hand, it confirms a limitation, for example, of urban development and of economic support activities to the tourist-recreational ones in the constrained areas, on the other hand, it contributes to increasing the market values of real estate and becomes a precondition for the development of this activity in the areas closest to and not subject to specific constraints.

The theoretical approach of reference for the determination of the co-benefit generated by the action of protection of natural capital is that of the Total Economic Value (TEV) [94-96].

Among the methods presented in the literature for the monetary evaluation of the benefits produced by environmental resources, we used the Contingent Valuation for the determination of the landscape co-benefits for citizens and the Travel Cost Method for those of tourists.

\subsection{Contingent Valuation Method (CVM)}

$\mathrm{CV}$ is a direct method that allows the evaluation of public or mixed goods, without market based on the recognition of the preferences expressed directly by the consumer, current or potential [97-109], and then is used for the estimation of TEV, making it particularly suitable for the evaluation of benefits in Cost-Benefit Analysis [110].

This method assesses willingness to pay (WTP) or to accept (WTA) in line with a certain offer of a public good [111].

For the implementation of $\mathrm{CV}$, a reference market is simulated for the estimated asset, and a statistically significant sample is selected that represents the population potentially interested in that asset. Within the market thus configured, the willingness to pay (WTP) or to accept (WTA) a sum of money for the good or service is detected through direct interviews [112,113].

The definition of the structure of the questionnaire is the fundamental moment in the development of the evaluation, as it must be able to induce the respondents to declare their real preferences. The questionnaire consists of three sections:

1. The first describes the effects of the intervention or policy, the contingent market and the conditions of access to the works or benefits of the policy (introductory section);

2. In the second, the respondent is invited to declare his WTP for access to the work or the results of the policy described (evaluation section);

3. The third section collects socio-demographic information on respondents that are useful to characterise their profile, understand the reasons for the declared WTP and verify the understanding of the survey and the evaluation request (final section).

In this case, the close-ended response format was used, which offered the advantage of administering the questionnaire without direct interaction, reaching a high number of respondents who had the opportunity to choose between some suggested values, without prejudice to the possibility of showing a willingness to pay nothing. The questionnaire was administered via a digital platform.

In this study, the respondent was asked to declare their first preference based on a set of values presented in the final structure of the questionnaire, obtained from a preliminary phase of analysis and verification conducted by administering some questionnaires constructed using the multiple-bounded discrete choice technique. The final structure of the questionnaire reduces the starting point bias problem because the interviewee is called 
upon to express themselves on a set of values resulting from the individual preferences of the sample of population interviewed at the preliminary stage and not by a single value fixed a priori.

\subsection{Travel Cost Method}

The Travel Cost Method (TCM) was developed by Clawson [114], initially suggested by Hotelling [115], to estimate the social benefits of recreation in natural sites. The method assumes that the recreational benefits in a specific site can be derived from the demand function, estimated by observing the behaviour of users, in relation to the costs incurred by them for number of visits. In particular, the journey plan represents the willingness to pay people to visit the site in question and serves as a proxy for its value [116-121]. Based on the assumption that the visit to a recreational site decreases as the cost of travel increases, it is possible to construct its curve and estimate the surplus for consumers and the total value.

This document applies a single-site ITCM [122].

A demand function can be represented by Equation (1):

$$
r=f\left(t c_{r}, t c_{s}, y, z\right)
$$

where $t c_{S}$ is the vector of travel costs to other places of leisure, $y$ is the vector of incomes, and $z$ is a vector of socio-economic variables that are believed to influence the number of journeys.

The total consumer surplus for travel to the site during the season is the difference between total availability to pay for travel and what they pay for access. It is called individual access value for the site.

A linear version of Equation (1) corresponding to Equation (2):

$$
r=\beta_{t c_{r}} \cdot t c_{r}+\beta_{t c_{s}} \cdot t c_{s}+\beta_{y} \cdot y+\beta_{z} \cdot z
$$

In the application, then, we try to estimate Equation (2) using site visit data.

The data for the implementation of the model are collected through a survey, conducted with the administration of a questionnaire. The questionnaire structure should be simple and comprehensible, and instrumental in acquiring all the information needed to implement the model. As a rule, it is structured in two different sections. The first section aims to measure the costs incurred for the visit, the number of visitors, the municipality of residence, distance travelled, the motivation of the visit and their general attitude towards the site. The second section focuses on the socio-economic characteristics of the respondents, namely age, sex, income, occupational status, educational qualifications, number of family members and the type of recreational activity carried out. Prior to the start of the survey, it is necessary to implement a pilot phase to identify potential problems during the conduct of the survey.

\subsection{Efficiency Criteria for Policies to Protect the Natural Heritage and the Performance of the Management Plan}

A discounted cash flow analysis (DCFA) was carried out in order to calculate the cost-effectiveness and the financial sustainability of actions to protect the natural heritage [123-129]. In this respect, two scenarios were assessed. The first scenario analyzes and compares an upstream intergenerational solidarity expressed by the Social Discount Rate (SDR) and a downstream intergenerational solidarity expressed by Average Period (AP). The AP may be considered as an indicator of socio-economic stability and confidence in the continuity of the political-administrative system and in social communication. Therefore, this scenario aims at identifying the propensity of the public to choose investments caracterized by a higher AP. The second is aimed at assessing the advantages of private entities operating in the tourist-recreational sector and pursuing the sub-objective of protection, that is, the development of this sector. 
In this case, the costs are those of plant and management provided in the Management Plan and the benefits are those of landscape for the citizen and the tourist, i.e., the cobenefits of policies for the protection of natural resources.

The cost-effectiveness and the financial sustainability of actions were calculated from the perspective of different results and indices.

(1) The net present value (NPV) is the sum of the incoming and outgoing cash flows, that is, revenues $(R)$ and costs $(C)$, over a defined time horizon $(T)$, discounted at the discount rate $r$. NPV is less, equal or more than the (net) future value (FV) if the discount rate $(r)$ [130-133] is more, equal or less than $0 ; N P V$ is expected to be significantly positive in case of a private player (Equation (3)):

$$
N P V=\sum_{i=0}^{T} \frac{R_{i}-C_{i}}{(1+r)^{i}} \geq 0
$$

(2) The total rate of return $(T R R)$ is the more significant index of profitability and thus the ratio between $N P V$ and the present cost; TRR should be greater than the opportunity cost of capital $c_{k}$ (Equation (4)).

$$
T R R=\frac{\sum_{i=0}^{T} \frac{R_{i}-C_{i}}{(1+r)^{i}}}{\sum_{i=0}^{T} \frac{C_{i}}{(1+r)^{i}}} \geq c_{k}
$$

(3) The internal rate of return (IRR) is the discount rate $r_{I R R}$ at which $N P V=0$, that is, the maximum rate of return that can be extracted by an investment; it only depends on the distribution of the stream along the time horizon of the investment (Equation (5)):

$$
\left.\sum_{i=0}^{T} \frac{R_{i}-C_{i}}{\left(1+r_{I R R}\right)^{i}}\right)=0
$$

(4) The discounted payback period $(D P b P)$ is the number of years it takes to break even from undertaking the investment cost $\left(I_{0}\right)$ by discounting future cash flows and recognizing the time value of money $(r>0)$ [124-136]; the higher the discount rate, the longer the $\mathrm{DPbP}$. More simply, a payback period $(P P)$ can be calculated without considering the time preference rate $(r=0)$ [137-139]. In general, $P P$ is the ratio between the total investment cost and the annual constant or average cash flow. Often, the variability of the cash flow over the lifetime of the project reduces the reliability of the formulas usually implemented for $D P P$, and thus a more general formula can be proposed considering $N P V(i)$ (Equation (6)), and then:

$$
D P b P=i_{N P V(i)=0}
$$

(5) The average period at the rate $r\left(A P_{r}\right)[140,141]$ is a sort of time elasticity that can be considered as the average period of deferment of the $i_{t h}$ annual net discounted cash flows $\left(C F_{i}\right)$ given the discount factor (Equation (7));

$$
A P_{r}=\frac{\sum_{i=0}^{T} \frac{i C F_{i}}{(1+r)^{i}}}{\sum_{i=0}^{T} \frac{C F_{i}}{(1+r)^{i}}}
$$

The discount rate $r$ is an important indicator of the intertemporal solidarity practiced with the implementation of the project, and it enables two different and complementary prospects: the private one as means and the public one as end. 
Concerning the first one, the discount rate can be assumed as the well-known weighted average cost of capital (WACC), referred to the funds in terms of debt $(D)$ and equity $(E)$ (Equation (8));

$$
W A C C=\frac{i_{d} D+i_{e} E}{D+E}
$$

where $i_{d}$ is the interest rate for debt and $i_{e}$ is the opportunity cost of equity that can be respectively referred to the active and passive interest rates charged to households and consumers, according to the statistics of Bank Italia (2019), set at 3.91\% (over 30 years loan life) and EURIRS (over 30 years loan life) set at $0.46 \%$; WACC is $4.37 \%$.

\subsection{Data Sources}

The data used for the estimation of the co-benefits are those obtained from the administration of questionnaires for two different targets of reference-the user-citizen and the user-tourist-previously tested.

The two questionnaires were structured to support, in the case of the target citizen, the identification of the preferences declared and finalized to the CVM, and in the case of the target tourist, the identification of the preferences detected and finalized to TCM.

The cost data declined in operating and operating costs are those provided for the actions identified in the Management Plan of the Special Area of Conservation and Nature Reserve Oriented "Timpa di Acireale".

The data on tourist flows are those collected by the Tourism Department of the Region of Sicily, in a period between March 2015 and March 2018, which include a provenance of visitors from 151 countries registered by number of arrivals, number of presences and number of occupied facilities.

The data on the cost of travel include, if the tourist reaches the site with an air flight, the cost of the air ticket, the expenses incurred to arrive from the airport Fontanarossa of Catania, up to Acireale (Alibus bus or Alibus train); if the tourist reaches the territory by his own means, the cost of fuel, highway ticket and parking; the cost of overnight stay was estimated by looking at the offers of the 64 accommodation facilities in the town of Acireale (Booking.com, accessed on 2 March 2019). The average daily price of accommodation is EUR 69.40. The costs charged to the cost of the trip will be specified in the results section.

\subsection{Sample Validation and Correlations between Variables}

The sample size, both in the case of the detection of preferences of clarified and finalized to the CVM and in the case of preferences detected and finalized to TCM, can be validated with reference to causal samples using the formula in Equation (9):

$$
n=\left(u \frac{\sigma}{e}\right)^{2}
$$

where:

$n=$ number of interviews;

$u=$ standardized variable (measures the degree of certainty that the sample correctly represents the population within a defined margin of error; the probability typically associated with estimates can be assumed to be $90 \%$ or $95 \%$, which corresponds to variable $u_{0.90}=1.65$ and $u_{0.95}=1.95$, respectively);

$e=$ maximum error: deviation of the estimated value deemed acceptable in relation to the actual value depending on the type of estimate and the expected value;

$\sigma=$ standard deviation of the dependent variable.

To assess the correlations between WTP and the socio-economic variables considered and, in the case of TCM, to select the variables significantly related to the number of trips to be included in the statistical model, a $\chi^{2}$ test statistical independence test is applied. 


\section{Materials-The Special Area of Conservation and Oriented Nature Reserve "Timpa di Acireale"}

The Natura 2000 network is the main instrument of the European Union's policy for the conservation of biodiversity. It is an ecological network spread throughout the Union, established under Directive 92/43/EEC "Habitats", to ensure the long-term maintenance of natural habitats and species of flora and fauna threatened or rare at community level. The Natura 2000 network consists of Sites of Community Interest (SCI), identified by the Member States in accordance with the Habitats Directive, which are subsequently designated as Special Areas of Conservation (SAC) and include the Special Protection Areas (SPA) established pursuant to Directive 2009/147/EC "Birds Protection Areas".

In Sicily, the natural heritage recognized by the protection and enhancement measures consists: 257 ZSC - Special Areas of Conservation, established in accordance with the Habitats Directive (Directive no. 92/43/EEC, art. 4) and D.P.R. 357/97 (art. 3 comma 2), DM 17 October 2007 (art. 2); 5 marine protected areas and 77 regional nature reserves (integral, oriented, special and genetic) established by L. R. 6 May 1981, n. 98 (Regulations for the establishment in the Sicilian Region of parks and nature reserves. Coordi-nated Text, updated to Decree Department of Territory 30 December 1999 (S. O. G.U.R.S. 9-05-1981, n. 23), some of which are included in the SPAs (Directive 2009/147/CE) (Figure 2); 6 regional parks (Figure 3) [142].

\section{SCl and SPA}

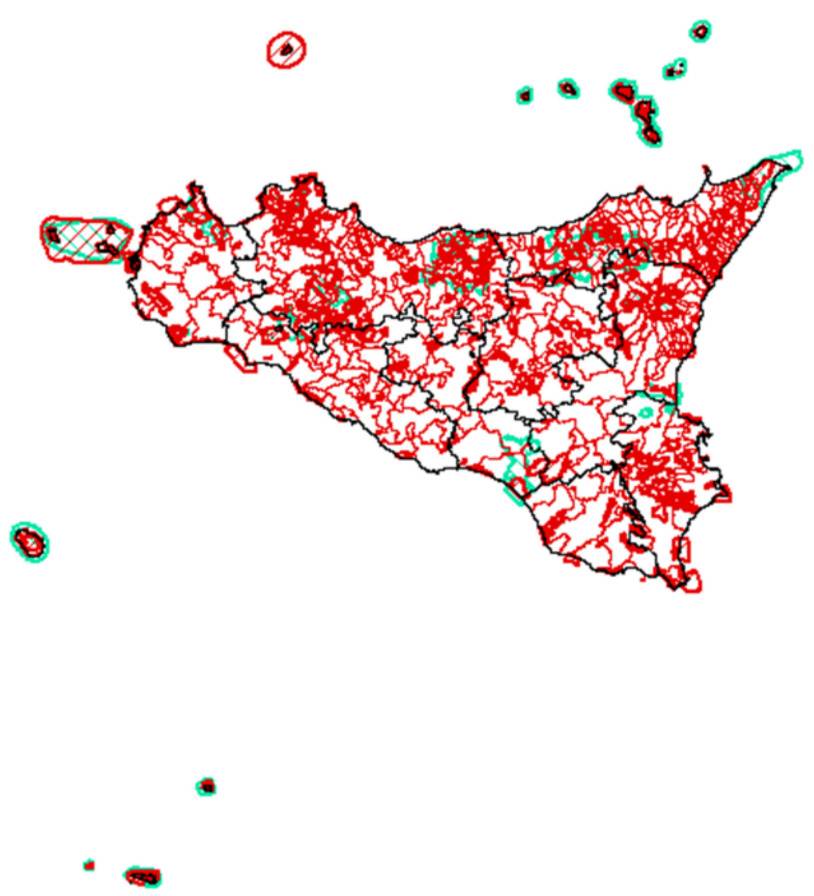

Figure 2. Location of Sites of Community Interest and Special Protection Areas in Sicily (our processing based on the data on Open data Sicily Region - Protected Areas and Natura 2000 Network [142]. 


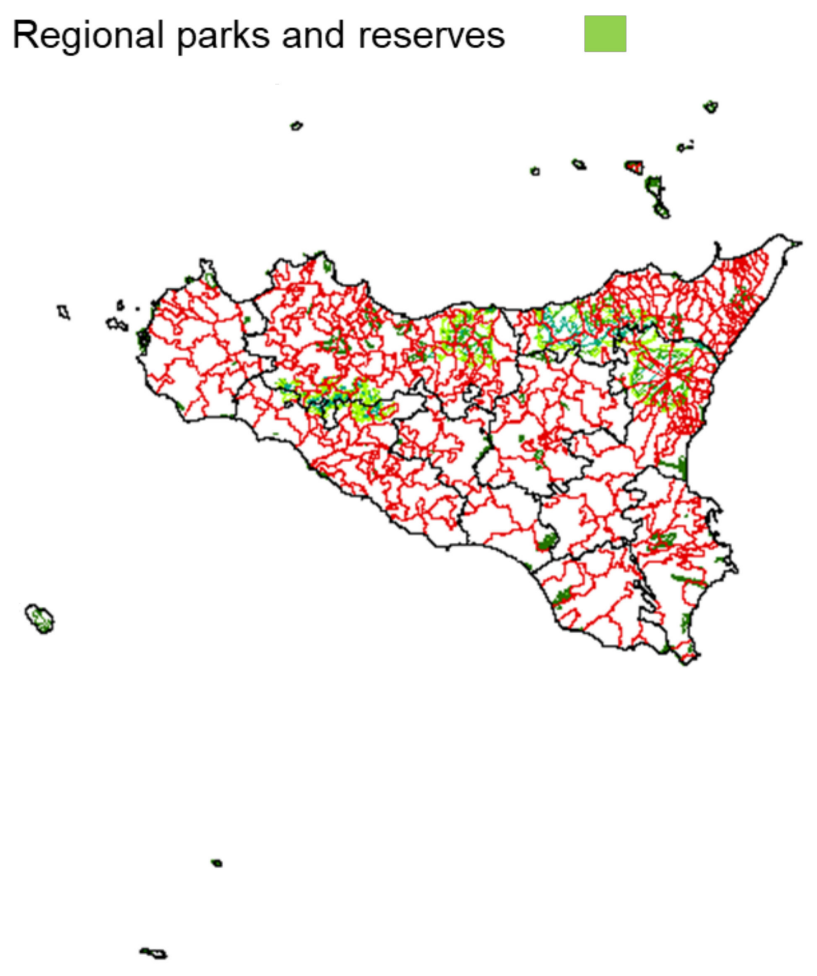

Figure 3. Location of regional parks and reserves in Sicily (our processing based on the data on Open data Sicily Region - Protected Areas and Natura 2000 Network [142].

"Timpa di Acireale" is a Special Area of Conservation with identification code ITA070004, which covers 236 hectares [143]. This area includes a coastal stretch of the northern Ionian slope of Etna. It is formed by lava rocks of various periods with a maximum altitude of about $200 \mathrm{~m}$. The bioclimate re-enters in the lower Mediterranean thermo with upper subhumid umbrotype.

It is a predominantly rocky territory directly influenced by marine factors. Euphorbia dendroides, that is a thermophilic spot, is quite widespread in it, which covers the most exposed rocky ridges.

The most protected surfaces of these rocky ridges are covered by patches of deciduous woods at Quercus virgiliana. [144]. In it are the well-represented perennial prairies of Hyparrhenia hirta and the sub-halophile aspects of Crithmum maritimum which colonizes the sea cliffs [144].

It falls in a tectonic area of regional importance with plant formations of considerable natural value, in a territory strongly man-made and urbanized. The importance of the site, despite its high degree of anthropization and its relative degradation, derives from representing the wooded edge at lower altitudes of the eastern Etnean slope. It represents a remnant of the "Bosco d'Aci", which at the beginning of the 19th century covered a wide strip of the eastern slope of Etna. [144].

These edges are currently the only natural areas where a portion of the much richer and more articulated forest fauna of the Etnean foothills has been preserved, and they represent places of refuge for numerous species of vertebrates that otherwise would have already disappeared from the entire area. It still preserves a significant fraction of the invertebrate fauna of the foothills of Etna with numerous endemisms and rare and very localized species [144].

The strategic importance of the site for the protection of biodiversity is therefore quite clear. In the same area of the SAC is presented the Nature Reserve Oriented "The Timpa of Acireale" which was established definitively, after long and troubled vicissitudes, only in April 1999 by the Department of Territory and Environment of the Sicily Region, thanks 
also to a very wide movement of opinion and the sensitivity of the inhabitants of the territory.

The reserve was established for the following reasons: "the presence of Mediterranean vegetation, for the panoramic view, for the geovolcanological peculiarities and for the presence of an uncontaminated marine environment" [145]. The creation of the reserve is intended to allow the protection, conservation and enhancement of the natural, geological and landscape heritage falling within this area. This area, despite its high degree of anthropization, still preserves a part of the "Bosco d'Aci", that is of a wooded area that extends from the eastern side of the Etna up to the sea. [145].

These areas have allowed the conservation of rich forest fauna and large invertebrate fauna of the Etnean foothills and are an important refuge for many species of vertebrates. The protected area, extended to 225 hectares and entrusted in management to the Regional Department Company State Forests, falls entirely in the territory of the municipality of Acireale in the province of Catania, exactly between the hamlets of Maria S.S. delle Grazie and Santa Maria Ammalati [145]. Reserve has been divided into two areas in which specific destinations of use are foreseen.

Zone A (Core Areas) comprises the narrow coastal strip between the Gazzena area and the town of Santa Maria la Scala, part of the Timpa Falconiera and Timpa Belfrontizio (dark green);

Zone B (Buffer Areas), under controlled development, comprises the sub-flat area of the Gazzena and the land beneath the Falconiera and Belfrontizio Timpe (in light green).

The Timpa area is one of the most important examples of the Etneo coastal landscape. The terraces made of lava stone along the steeper slopes, the small walkways, the inner roads, the irrigation channels and the dry stone walls constitute the memory of this territory (Figure 4).

a) Route "Chiazzette"
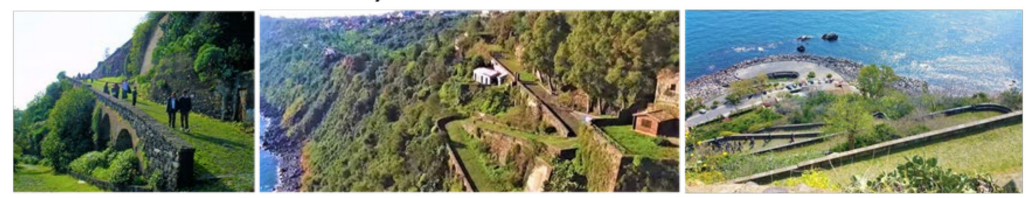

b) Route "Acque del Ferro"

c) Route "Acque Grandi"
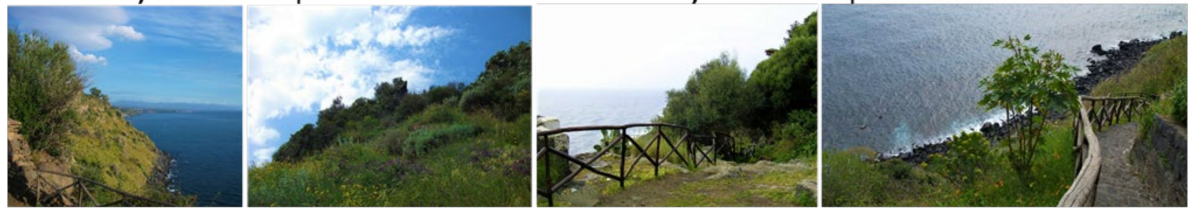

d) Route "Pietra Monaca"
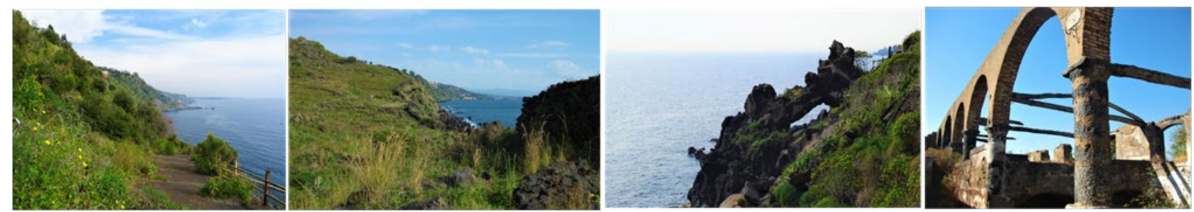

e) Route of the old railway track
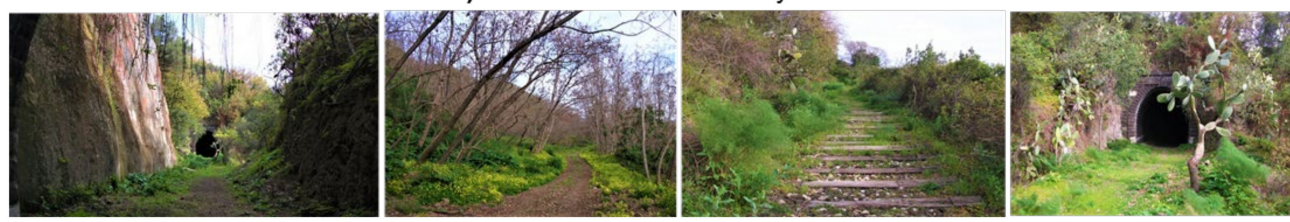

Figure 4. The landscape routes in the Nature Reserve "Timpa di Acireale": (a) Route "Chiazzette"; (b) Route "Aqua del ferro"; (c) Route "Aque Grandi"; (d) Route "Pietra Monanca"; (e) Route of the old railway track (our source). 
The Habitats Directive provides that, for areas included in the Natura 2000 network, appropriate conservation measures include the possible implementation of Management Plans [31,32] with the fundamental aim "to contribute to the preservation of biodiversity through the conservation of natural habitats and of wild fauna and flora in the European territory of the Member States to which the Treaty applies". In other words, the main objective of the Management Plan is to maintain the habitats and species present in the sites of community interest in a satisfactory state of conservation, providing strategies and identifying interventions in accordance with art. 6 of the Habitats Directive.

The general objectives of the Management Plan for the site "Timpa di Acireale" are identified and defined to ensure the conservation of habitats and species of fauna and botany and the restoration of ecological balance [145].

As part of the management of the site, the general objectives (Appendix A) that aim at the conservation of habitats, species and environmental resources in general are:

- Objectives of management and conservation of existing habitats and species;

- Rehabilitation/restoration objectives;

- Objectives for the reconstruction of new habitats/environments;

- Impact mitigation objectives.

The objectives for territorial needs and economic development are:

- Objectives of maintaining and restoring the traditional agricultural landscape and enhancing territorial resources;

- Objectives of site use, communication, training and exploitation of sustainable economic activities.

The identified and defined management actions are grouped into different categories according to the nature and general objective they pursue. In line with the general objectives and strategic lines identified, the following actions are defined (Appendix B):

- Monitoring and research actions;

- Management and conservation of existing habitats and species;

- Rehabilitation/restoration of ecological integrity;

- Maintenance and restoration of the traditional agricultural landscape and enhancement of territorial resources;

- Reconstruction of new habitats/environments;

- Mitigation of impacts;

- Use of sites, communication, training and exploitation of sustainable economic activities.

For each action, an annual cost and the duration of the related actions have been identified in the Management Plan [146].

\section{Results}

Two questionnaires were administered: one for residents of the municipal territory and in nearby areas, and the other for local and supralocal tourists. The questionnaires were administered via an online platform.

Their structure is as follows:

1. Descriptive introduction of the Natura 2000 network and the site of "Timpa di Acireale" (introductory section);

2. Definition of the contingent market (evaluation section);

3. Socio-economic, behavioural and aptitude information of the interviewee (final section).

The structure of the questionnaire for the segments of users considered differs in some parts of the sections because for the estimation some insights for specific targets are instrumental [147-150]. The questionnaires are available on Zenodo with the following doi:10.5281/zenodo.4733858.

The administration of the questionnaires, which were tested beforehand to improve the general structure, covered a period ranging from December 2018 to March 2019. The survey involved 234 visitors, 159 residents in the municipality or neighbouring municipalities and 75 non-residents. 
Results of questionnaires for user-citizen and tourist users are available on Zenodo with the following doi:10.5281/zenodo.4733858, which can also be found in Supplementary Materials.

\subsection{WTP of User-Citizen}

The questionnaire replies were analysed to determine a probability density function for calculating the willingness to pay.

The sample was asked to express the willingness to pay based on a scenario in which it is planned to set up a fund with annual donations, managed by an Environmental Association committed to the protection and sustainable development of the Oriented Nature Reserve. The survey of the willingness to pay of citizens-users shows that $74 \%$ of the sample interviewed are willing to pay an annual fee to a fund managed by an environmental association, while $25 \%$ are not willing to pay any fees. The sample, in this case, has only one outlier as a single subject declares a WTP value too high and inconsistent with its average value and not consistent with the declared data in terms of income.

In this case, the average is the trend index that best represents the variable of a set of observations.

In this case, the mode and the median are not adequate to best represent the variable of a set of observations because, in the first case, the frequencies observed for some values coincide, and in the second case, because its use is preferable when the CV is developed according to the bidding game format method, in which respondents are imposed dichotomous choices for each sum [151,152].

A measure of dispersion is used to measure variability, the standard deviation or quadratic mean deviation, which makes it possible to assess how much the values are scattered around the mean. In this case it is worth 15.42 .

The standard error of the mean allows one to understand how much the sample mean $\bar{x}$ of the WTP is representative of the true average of the population $\mu$.

Thus obtaining $\sigma_{\bar{x}}=$ EUR $1,23$.

The standard error allows one to calculate the confidence intervals of the average, that is, the intervals within which we can affirm with a certain level of confidence that the true $\mu$ average of the population is found at $95 \%$ confidence level.

Therefore, it is possible to say that, with a $95 \%$ probability and a $5 \%$ risk of error, the average $\mu$ of the availability to pay of the entire population is between EUR 12.04 and EUR 16.85 for a fund managed by an environmental association.

The values of $\mu$ are within the range (EUR 12.04; EUR 16.85), and the average of them allows one to identify a value of the WTP equal to EUR 14.44.

For a correct implementation of the CVM, it is necessary to identify a representative sample of the population.

Random sampling was carried out, in which every one of the populations has the same probability of being part of the sample. For a random sample to be statistically significant, it must have an appropriate size, which was evaluated based on Equation (9).

The size of the sample representative of the estimated population, admitting an error $e$ of $10 \%$ of the WTP (on average, EUR 14.44) and the $\sigma$ of the WTP being, on average, equal to EUR 15.42, with $u=1.18$ for a probability of $88 \%$, is equal to 159 .

The sample appears to be just sufficient since it corresponds to the number of the interviewed excluding outliners.

To understand if there is a correlation between availability to pay and other socioeconomic variables, the $\chi^{2}$ test was applied.

Contingency tables were constructed for WTP-gender, age, educational qualification, employment, income, commune of residence and environmental sensitivity-but in no case were correlations found between the variables.

The availability to pay total annual $W T P_{\text {year }}$ was estimated considering the average WTP previously calculated and the population of the municipality of Acireale, which 
by reference to ISTAT data 2018 , is 52,269 inhabitants. The $W T P_{y e a r}$ is equal to 754,764 EUR/year.

If the $W T P_{\text {year }}$ can be assimilated to a constant and unlimited flow of benefits and consider a social discount rate SDR calculated according to the STPR approach for Italy of $3.3[153,154]$, the value of the benefits produced using the resource for citizens is equal to EUR 22,871,647.

\subsection{Travel Cost Results}

In relation to the data of the sample interviewed, it was chosen to use the ITCM [118]. In particular, the model proposed in Equation (2) was simplified in relation to the information extracted from the results of the survey campaign conducted.

As for $t c_{S}$, the carrier of travel costs to other places of leisure, given that $63.33 \%$ of respondents said they spent a holiday in Acireale and visited the Nature Reserve Oriented, $53.33 \%$ of which runs only $15 \mathrm{~km}$, and given that tourists of supralocal origin, even in the preliminary verification phase of the questionnaire, were not able to provide clear data on preferences for other destinations, it was chosen not to consider it.

The random sample was statistically significant based on Equation (9) for an error $e$ of $15 \%$ with reference to the average number of visits to the site of 2.81 , a $\sigma$ of 5.95 and $u=0.615$ for a probability of $72.91 \%$.

Also in this case, to verify the correlation between the site view frequency and other socio-economic variables, the $\chi^{2}$ test was applied. Contingency tables were constructed for the number of trips-gender, age, qualification, employment, income, municipality of residence and environmental sensitivity-but in no case were significant correlations found between the variables.

Then for the determination of the cost of travel and for the reasons mentioned above, a simplified version of Equation (2) was considered, namely $r=\beta_{t c_{r}} \cdot t c_{r}+E$.

The $t c_{r}$ vector was calculated as per capita outward and return journey for each interviewee. It includes the cost of fuel per litre, which varies in a range from EUR 1.42 to EUR 1.52 [155], considering urban and extra-urban $\mathrm{km} / \mathrm{l}$ consumption for a small car [156] and a possible cost of motorway ticket or a stamp (German motorways) and the cost of the parking ticket of $0.60 \mathrm{EUR} / \mathrm{h}$.

In addition, for tourists who declared that they reached the site with their own car, the cost of the ticket of the ferry Messina-Reggio Calabria was considered.

For tourists who reached the site with the rental of a bus with a driver (capacity 20-30 passengers), a cost between EUR 250 and EUR 300 or other tickets for connections through public transport (train or bus ticket) were considered. When calculating the cost of travel, the expenses incurred by the tourist for food, i.e., packed lunch or restaurant, and those for overnight stays were considered.

The opportunity cost of travel time and time spent at the site was estimated with a reference value compared to equivalent paid working hours [157,158].

The questionnaire given to tourist users also found them willing to pay a ticket to access the Reserve.

In particular, four models were elaborated in which the number of visits is related: to the cost of the trip (constituted fuel, highway ticket, ferry, parking and cost of time) (TC); to the cost of travel and eventual ticket of access to the site (TCT); the cost of travel and expenses for food and/or accommodation, cost of travel and possible ticket access to the site (TCA); the cost of travel, food and possible ticket access to the site (TCAT).

The consumer surplus calculated as the area underlying the demand curve identified by the development of the linear regression model identified the following annual values: EUR 1415.83 for TC; EUR 1530.10 for TCT; EUR 1722.42 for TCA; and EUR 1835.23 for TCAT.

To extend the estimate of the Travel Cost conducted for the sample of 75 individuals to the municipal tourist flow, we analysed the tourist flow that the Observatory Department of Tourism of the Sicilian Region related to March 2015-2018. Several correction factors were introduced for the estimation of the TC, considering the significance of the sample found, 
the estimated frequency of visits to the site and the percentages of the two tourist segments, that is, local and supralocal. These data show a presence of visitors from 151 countries. Based on the sample data, it was found that $82.67 \%$ of the tourist flow with destination Acireale belongs to the segment of local tourists and $18.33 \%$ to that of supralocal tourists.

Implementing all correction factors, a value of $T C_{\text {year }}$ for local tourists is estimated to be EUR 99,678.12 and for supralocal tourists EUR 2276.39.

If the $T C_{\text {year }}$ can be assimilated to a constant and unlimited flow of benefits and considering a social discount rate SDR calculated according to the STPR approach for Italy of 3.3 [140], the value of the benefits produced using the resource for the local tourists is equal to EUR 3,020,549.03, while that for supralocal tourists is EUR 68,981.58, and therefore for a total of EUR 3,089,530.61.

\subsection{Efficiency Measures of Policies to Protect the Natural Heritage and the Performance of the Management Plan}

For the evaluation of the efficiency produced by the natural heritage protection policies and for the performance of the management plan adopted for the Natura 2000 site "La Timpa di Acireale", the criteria proposed in Section 3.3 were calculated.

In particular, for the purposes of estimating the different criteria, account shall be taken of the installation and management costs provided in the Management Plan and the landscape benefits calculated in the preceding sections.

The estimated costs for the actions set out in the Management Plan are shown in Appendix C.

There is no certainty that the actions provided in the Management Plan have all been implemented or if the start of activities coincides with its approval date; however, considering a hypothesis of regularity of the interventions, the total expenditure until 2018 incurred by the state-owned forest management body can be estimated at EUR 7,409,000. In addition to the costs related to the specific actions, we must also consider the costs of ordinary and extraordinary maintenance of the Reserve.

Since it is not specified whether this body has assigned work units to the exclusive performance of these tasks, they are nevertheless counted at 180,000 EUR/year, assuming that these actions are carried out by five units with a gross annual remuneration of EUR 36,000.

The benefits are those generated in the tourist-recreational and cultural-social sector, that is, the co-benefits of policies for the protection of natural resources.

From the comparison between the operating and management costs of the Oriented Nature Reserve and the benefits produced, it is possible to evaluate the efficiency of resource protection policies and measure the performance of the Management Plan. This analysis aims to identify economic resources that can be allocated to strengthening the protection actions in the public perspective and tourism-recreational enhancement in the private perspective.

A sensitivity analysis was conducted for both scenarios introduced in Section 3.3 to assess the effects of changes in SDR variables [159], plant costs, operating costs and co-benefits and aimed at identifying a range of possible solutions that, in compliance with economic and financial feasibility, can identify additional resources to improve the level of protection action and increase co-benefits for the enhancement of the tourist-recreational sector and that, for the local community and globally, will lead to better communication between social sub-systems.

Based on this analysis, the efficiency of resource protection policies and the performance of the Management Plan are sufficient, as evidenced by the indicator values in the first column of Figure 5. An increase in co-benefits increases the first four indicators, does not change the fifth and decreases the last; an increase in plant and management costs makes the investment not convenient; an increase in the SDR reduces the first four indicators, does not change the fifth and increases the last, and its decrease would lead to the opposite effect on the condition of promoting higher intergenerational solidarity (Figure 6). 
From this, it is possible to increase the level of protection actions only by attracting greater tourist flows and increasing the environmental landscape sensitivity of citizens and tourists.

This shows that the level of protection can only be increased by attracting more tourists and by increasing the environmental and landscape sensitivity of citizens and tourists.

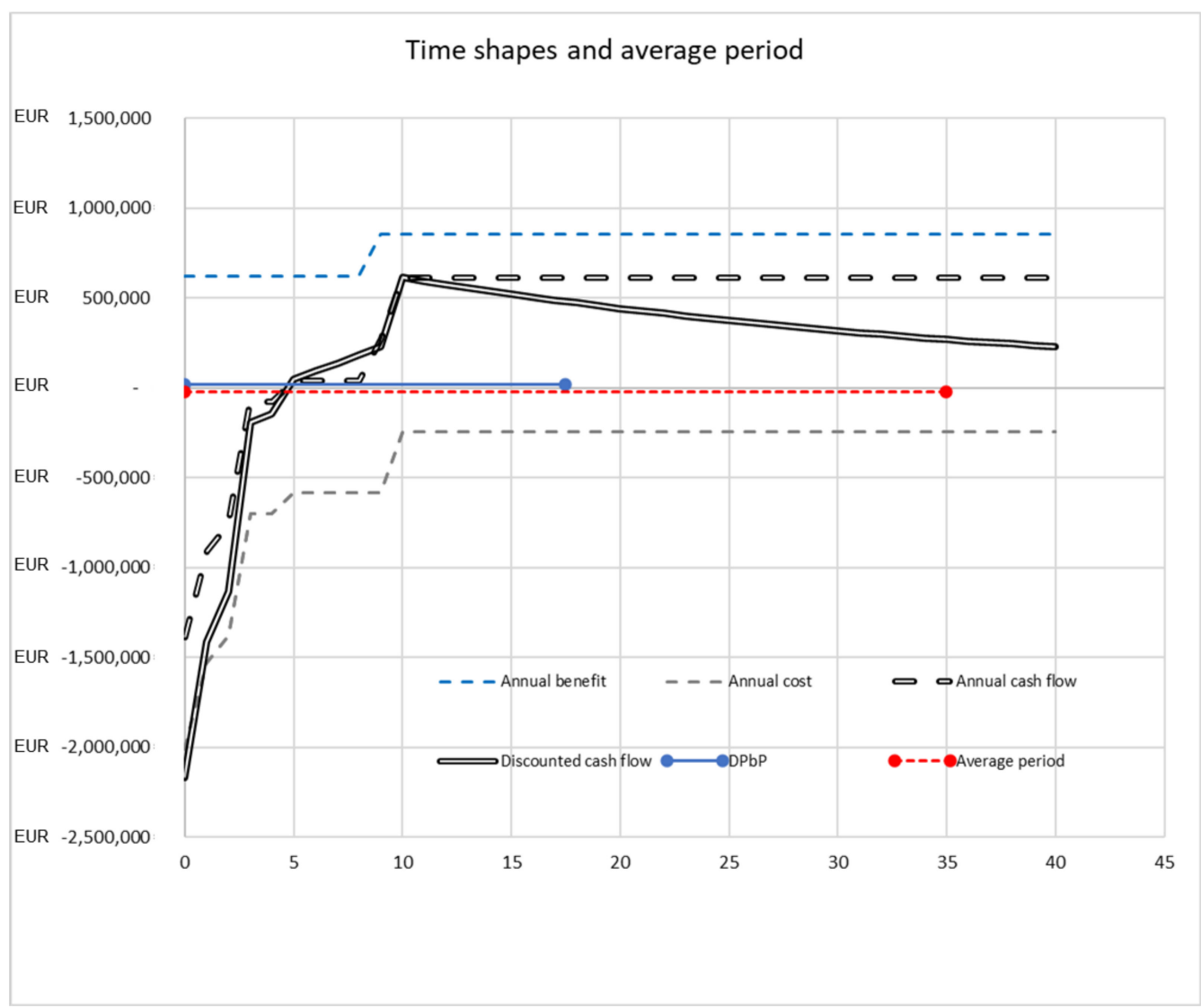

Figure 5. The investment time shapes and average period from public point of view.

\begin{tabular}{|c|c|c|c|c|c|}
\hline \multicolumn{6}{|c|}{ Sensitivity analysis } \\
\hline & & Co-benefits & Plant costs & Operating costs & SDR \\
\hline VAN & EUR $7,815,714$ & 3.09 & -1.20 & -1.51 & 1.29 \\
\hline Co-benefit/Cost & 1.48 & 0.68 & $-\phi .68$ & -0.68 & 0.68 \\
\hline TRR & $48 \%$ & 2.08 & -2.08 & -2.08 & 2.08 \\
\hline IRR & $5.12 \%$ & 2.93 & -2.15 & -1.37 & 1.37 \\
\hline $\mathrm{DPbP}$ & 17.00 & 0.00 & 0.00 & 0.00 & 0.00 \\
\hline AP & 34.97 & -1.54 & 1.12 & 0.69 & 0.63 \\
\hline
\end{tabular}

Figure 6. Sensitivity analysis—investment from public point of view.

From a private-sector perspective, the results are sufficient, which is evidenced by the values of the indicators in the first column of Figure 7.

An increase in co-benefits increases the first four indicators and decreases the last two; an increase in plant and management costs makes the investment not convenient. An increase in the WACC makes the investment not convenient.

From this, an increase in the capacity of the resource to intercept greater tourist flows, currently underdeveloped, could contribute to the increase in the production of co-benefits is closely linked to the protection and conservation of the resource, and its attractiveness from a tourist and recreational point of view.

Currently the ability to intercept the flow of tourism by the Nature Reserve Oriented is quite low, its expansion could support the development of the tourism sector, increasing 
the co-benefits produced in favour of this sector, which may consequently increase its level of competitiveness.

A balanced strengthening of the tourist-recreational activities in the site, could consequently free economic resources from the private sector that can be committed to increase the level of protection and conservation of the Nature Reserve Oriented.

The creation of positive synergies between resources and sectors can foster co-generative development, capable of increasing territorial capital creating positive synergies between sectors and co-generative development (Figure 8).

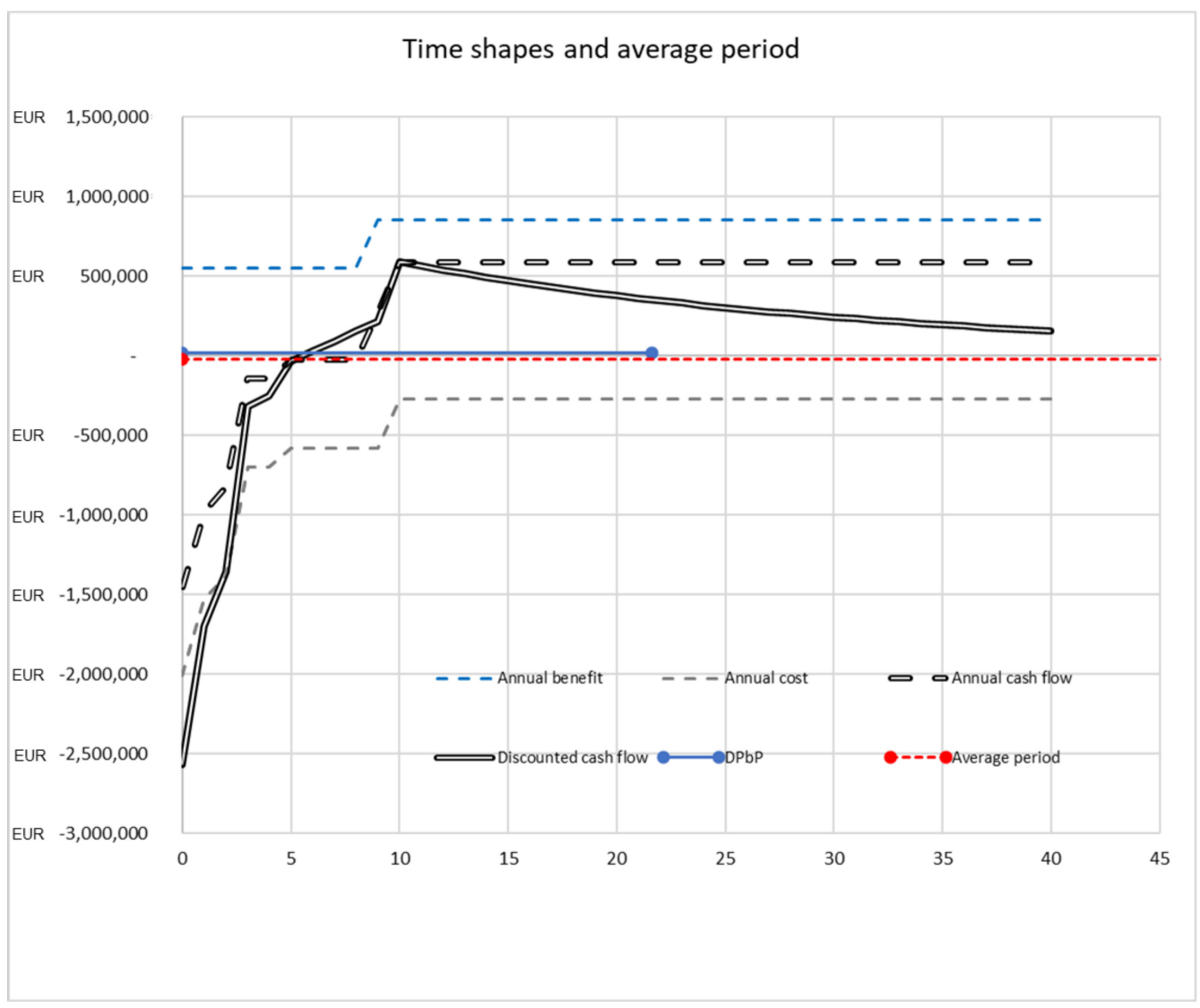

Figure 7. The investment time shapes from private point of view.

\begin{tabular}{|c|c|c|c|c|c|}
\hline \multicolumn{6}{|c|}{ Sensitivity analysis } \\
\hline & & Co-benefits & Plant costs & Operating costs & WACC \\
\hline VAN & EUR $4,436,083$ & $4 ! 87$ & -90.22 & -90.26 & -2.75 \\
\hline Co-benefit/Cost & 1.26 & 0,79 & -0.79 & -0.79 & -0.79 \\
\hline TRR & $26 \%$ & $3: 85$ & -3.85 & -3.85 & -3.85 \\
\hline IRR & $2.90 \%$ & $4 \sqrt[48]{2}$ & -3.10 & -2.41 & -2.76 \\
\hline $\mathrm{DPbP}$ & 22.00 & -455 & 0.00 & 0.00 & 0.00 \\
\hline AP & 48.86 & -309 & 2.25 & 1.70 & 1.92 \\
\hline
\end{tabular}

Figure 8. Sensitivity analysis-investment from private point of view.

\section{Discussion}

Designation of valuable biodiversity areas such as Natura 2000 sites does not automatically guarantee that their conservation status is maintained or restored. Although designation is a valuable first step, proper management and restoration of Natura 2000 sites is necessary to ensure that conservation objectives-and their socio-economic benefits-are achieved in practice. This requires sufficient financial resources, capacity to carry out management activities in an effective and continuous way and support from both stakeholders 
and decision-makers alike [83]. The final success of the Natura 2000 network in achieving its objectives depends on the commitment of all stakeholders involved in maintaining the network. Demonstrating socio-economic benefits arising from the management of the site can help to get support between different stakeholders. Demonstrating the benefits can pave the way for incentives and the creation of new partnerships for the conservation and/or sustainable use of Natura 2000 sites. In particular, it can help provide new and innovative sources of funding for the management site [77].

It has been estimated that management of Natura 2000 would require approximately 5.8 billion euro/year. It is difficult to determine the overall funding available to support the network [81]. However, the financial allocations for Natura 2000 from the EU budget are between EUR 550 and EUR 1.150 million/year [77]. Financial resources are not yet adequate to ensure effective management and restoration of the network. As a result, the lack of adequate resources currently poses a significant risk to the achievement of conservation objectives and also decreases the amount of co-benefits associated with Natura 2000 sites. In the light of the current economic crisis, investments in protected areas could lose momentum and priority within the EU's political agenda, with the risk of a reduction in resources to support their management and protection. The public funding that must continue to be present must be supported by new sources of funding to ensure effective operation of the network, such as:

- Wider access to existing public funds (such as EU funding): identification and demonstration of links between the Natura 2000 network with broad socio-economic benefits, such as natural risk management, climate change mitigation and adaptation, water management and tourism [160], can facilitate access to a wider range of EU funds, including funds to support regional and rural development (e.g. European Regional Development Fund, European Social Fund, European Fisheries Fund and European Fund for Agriculture and Rural Development) [83].

- Payments for environmental services (PES): evaluating the benefits of conservation can attract funds from stakeholders benefiting from the ecosystem services provided by Natura 2000 areas. The benefits of habitat conservation to water retention and quality in an area can form a basis for establishing a payment scheme where the users of water [161] contribute to maintaining, managing and/or restoring the Natura 2000 site and its natural abilities to regulate the water flow. Similarly, the demonstration that Natura 2000 areas play a significant role in both storage and carbon capture, and thus in mitigating the effects of climate change, could make such areas eligible for carbon reduction funding [83].

- Revenue from certified and/or sustainable tourism products: with markets for sustainable products and/or an increase in biodiversity-friendly products, there are also growing opportunities to develop markets for certification products from or associated with Natura 2000 areas [77]. Leisure and tourism opportunities, including related activities, can provide a source of funding that helps to cover certain Natura 2000 opportunity costs and management costs [83].

- Public partnerships-private: many sectors of activity that benefit from the natural beauty and other features of the site or commercial activities that seek to create markets for products respectful of biodiversity can support funding for the protection and conservation of these areas [83].

Our proposal for an extension of the concept of co-benefits emerged and developed in the context of climate change policies promoted by the IPCC to include the protection and conservation of natural resources intends to promote an expansion of their operational dimension to enhance its effects. A perspective in which policies are only aimed at pursuing the objective of protecting the natural resource, without identifying the underlying objectives that it triggers and that involve other territorial resources, reduces the potentials of the policy itself to achieve communication between the natural, social and economic systems, through which their individual and shared values are generated and strengthened [162]. Systemic communication produces integration, shared values and 
coordinated development, whereas its low level or total absence produces isolation and reduces the potentials to generate values and development [162]. The perspective of a multidimensional policy, open to internalize and maximize all effects produced in a causal (co-benefits or co-costs) and not random (benefits/costs accessory or secondary) way, can produce value for a wider audience and address in a structured way the mediation of the opportunity costs generated by the policy itself, pursuing its overall objective more effectively. By interconnecting a plurality of subjects and resources, it is possible to promote a co-generative [163-167] model of development that leads to better systemic communication in the Luhmannian sense and is capable of increasing territorial capital [162]. The objective of protection of the Natura 2000 "La Timpa di Acireale" site and its strategies generate underlying objectives and programmes to be identified and developed on the scale of the various sectors involved. In this study, we addressed only the issue of landscape co-benefits generated by the site, highlighting those related to the local community and those related to the tourism industry [168]. The recognition of landscape co-benefits highlighted the significant potentials of the site protection and enhancement to produce well-being for the local community and to support the development of the tourism sector. The different sectors involved, namely urban planning and tourism planning, should develop appropriate strategies to maximise the effects and the opportunities offered by the site. In the context of urban planning, the site, given its location in the municipality, could partly compensate for the lack of green areas and foster the redevelopment of already existing pedestrian links in the historic centre of Acireale and its seaside villages of S. Maria La Scala, S. Caterina, S. Tecla and Capo Mulini.

In the field of tourism sector planning, the site could help improve the quality level of tourism. Both the cost-effectiveness analysis and the one aimed at verifying the financial sustainability of the actions to protect the site highlighted values of positive indicators but offered low margins to cover operating and plant costs [77-81]. Therefore, the level of protection provided to the site is minimal, and further implementations should involve the use of additional financial resources. Within the framework of the new policy perspective, additional resources to be allocated to strengthen the protection action could be found in the sectors where it generated the co-benefits, and therefore basing on the above-mentioned co-generative model.

\section{Conclusions}

The estimate of the co-benefits produced by the policies of protection of the natural capital (with reference to the landscape co-benefits only), considering the tourist-citizen, the local tourist and the supralocal tourist, identified a total value of EUR 25,961,177.61, with flows of annual co-benefits of EUR 754,764, EUR 99,678.12 and EUR 2,276.39, respectively. These relatively modest values are partly justified by the lack of the infrastructure required to support the use of the Oriented Nature Reserve.

As a matter of fact, the questionnaire to detect the WTP of citizens highlighted several problems related to the accessibility of the site, such as: the lack of information points and links to public transport, inadequate signage and lighting, the lack of garbage collection service and accessibility for the disabled.

A total of $64.15 \%$ of the sample of citizens expressed a negative opinion on the management of the Reserve.

On the other hand, the questionnaire showed that $92.45 \%$ of citizens are aware that the site is an Oriented Nature Reserve and that $66.67 \%$ considered this site important for the identity of the local community.

In total, $71 \%$ of the people interviewed visit the site at least once a year and $23.90 \%$ once a month; $90 \%$ enjoy the site for walking and enjoying nature and the beauty of the landscape; $98.11 \%$ are aware of the importance of natural services to regulate the environmental cycles; and $97.48 \%$ are aware of the function of natural habitat for the conservation of many animal species and the biodiversity and local resources for future generations offered by the site. 
A total of $76.73 \%$ of citizens declared that they oppose an extension of the Reserve area because of the limitations imposed by its restraints.

A total of $93.33 \%$ of the sample of tourist users declared that environmental protection is essential for sustainability; $42.67 \%$ highlighted the need for providing the site with refreshment points, $64 \%$ with toilets and $69.33 \%$ with guides.

A total of 52\% reported poor accessibility, 52\% the lack of organized activities, 53\% the absence of areas to support the fruition and $52 \%$ the lack of promotion by means of brochures, apps, social media and websites. On the contrary, $71 \%$ would be willing to pay a ticket to access the reserve area.

The results of the analysis of the tourist flow show that $82.67 \%$ of the site visitors are local tourists while $18.33 \%$ are supralocal tourists. The catchment area of the site is therefore mostly local, whereas supralocal tourism seems poorly developed so far. This is in contrast to the significance tourists attribute to the reserve, as shown by interviews of the sample, despite its poor integration in the tourist offer being pointed out.

The low level of communication between environmental resource and supralocal tourists reduces the capability of the site to generate value, compared to 151,266 arrivals in 2017 with a potential TC value of EUR 28,655,560.60, which highlights unexpressed potentials of policies to protect natural capital in order to adequately support the development of the tourism sector.

The low level of integration of the site visit into a tourist offer on a local scale, and, more significantly, on a supralocal scale, highlights the absence of a co-generative vision of development of the territorial resources. In fact, the visit to the site could be integrated on a local scale with the nearby fishing villages, on a supralocal scale, with the historical and cultural heritage of the Baroque city of Acireale with its food and wine excellences and its Carnival, and, on a territorial scale, with the UNESCO site of "Mount Etna" or the nearby UNESCO site of the "Baroque Towns of the Val di Noto".

Concerning the user-citizen, this site, given its location, could partially compensate for the lack of green areas of the city of Acireale. In addition, since it is located within the urban core of Acireale, which has an altitude above sea level of $161 \mathrm{~m}$, it could be developed as a panoramic promenade connecting the city centre to the seaside villages of S. Maria La Scala, S. Caterina, S. Tecla, Capo Mulini, Stazzo and Pozzillo.

The surveys conducted highlighted a high appreciation of the site by citizens and tourists as well but also several problems mostly due to poor maintenance and accessibility. Such criticalities could be easily removed, as long as the actions envisaged in the Management Plan are implemented. Surveillance and maintenance can be enhanced with the recruitment of specialized personnel; these actions can be supported by European funding and by means of building permission fees for small visitors' facilities that may be integrated into the site.

Therefore, the goal of valorisation of the site can be pursued with punctual actions complying with the original objective of protection.

The development of this site, if properly integrated in the creation of a local and territorial offer, could support the development of the tourism sector in a territorial context that already has a strong tourist vocation and a plurality of attractors of value [165].

The implementation of the site in an integrated tourist offer does not expose it to strong pressures because the area can be enjoyed only through trekking paths, which limits access, and in the city, there are several panoramic viewpoints that offer a magnificent view of the site and the Eastern Sicily's and Calabria region's coastline.

Therefore, the objective of protecting the natural heritage could generate an adequate level of co-benefits for the local community, in terms of identity, culture, environment, well-being and no profit activities to support its development.

This objective, interconnected with those of historical and cultural protection, wellbeing [169-171] and economic valorisation, can foster the creation of the co-generative model capable of generating a coordinated sustainable development of all territorial resources [172]. 
The decision-makers will have to identify additional co-strategies to promote the protection of natural resources and to foster the coordinated development of all territorial resources [173-175].

This research investigated only a part of the co-benefits produced by natural capital investment policies. Future developments will include the estimation of the other benefits of the tourism sector and the trade-offs that such policies generate on the real estate market [176-181]. The research was conducted in the pre-COVID-19 period; subsequent research works may require additional interviews concerning the adequacy of facilities and the level of vigilance.

Supplementary Materials: The questionnaires of user-citizen and tourist users and survey results are available on Zenodo with the following https: / / zenodo.org / deposit?page=1\&size=20.

Author Contributions: Conceptualization, M.R.T.; methodology, M.R.T.; software, M.R.T. and S.G.; validation, M.R.T. and S.G.; formal analysis, M.R.T.; investigation, P.M.; resources, P.M.; data curation, M.R.T. and P.M.; writing—original draft preparation, M.R.T.; writing—review and editing, M.R.T.; visualization, M.R.T. and S.G.; supervision, M.R.T.; project administration, M.R.T. and S.G.; funding acquisition, M.R.T. and S.G. All authors have read and agreed to the published version of the manuscript.

Funding: This work was financed by the University of Catania in a project entitled Architettura a Rischio: Demolire, Recuperare, Restaurare. Il tema della qualità nel progetto sul patrimonioARDeRe, scientific manager which is part of the general project "Piano della Ricerca Dipartimentale 2020-2022 of the Department of Civil Engineering and Architecture".

Institutional Review Board Statement: Not applicable.

Informed Consent Statement: Not applicable.

Data Availability Statement: Not applicable.

Conflicts of Interest: The authors declare no conflict of interest.

\section{Appendix A}

Table A1. Overview of the specific objectives and related priorities for action: short-term within 5 years-ST; long-term between 5 years and 10 years or more-LT; priority: high, medium and low [145].

\begin{tabular}{lcc}
\hline \multicolumn{1}{c}{ Specific Objective } & Time Frame & Priority \\
\hline $\begin{array}{c}\text { Adaptation of the infrastructural endowment of the site finalized to } \\
\text { the controlled and eco-sustainable fruition of the resource }\end{array}$ & ST & low \\
\hline $\begin{array}{c}\text { Adaptation of infrastructure and services compatible with the } \\
\text { sensitivity and load capacity of environmental components }\end{array}$ & ST & low \\
\hline $\begin{array}{c}\text { In-depth knowledge on the ecological characteristics of habitats, } \\
\text { wildlife and species of community interest present in the site and } \\
\text { evaluation of the development potential }\end{array}$ & ST & high \\
\hline $\begin{array}{c}\text { Deepen the knowledge of the territory and promote a respectful } \\
\text { approach towards nature in tourists }\end{array}$ & ST & medium \\
\hline $\begin{array}{c}\text { Increasing public awareness of development opportunities linked } \\
\text { to the Natura 2000 network }\end{array}$ & ST & medium \\
\hline $\begin{array}{c}\text { Conservation and improvement of the level of biodiversity at local } \\
\text { level, good conservation conditions and the representativeness of } \\
\text { habitats }\end{array}$ & LT & low \\
\hline $\begin{array}{c}\text { Conservation and upgrading of the traditional agricultural } \\
\text { landscape in order to enhance the ecological functionality of the } \\
\text { territorial system and the development of biodiversity }\end{array}$ & ST & high \\
\hline
\end{tabular}


Table A1. Cont.

\begin{tabular}{|c|c|c|}
\hline Specific Objective & Time Frame & Priority \\
\hline $\begin{array}{c}\text { Containment of offences and prevention of activities/actions to } \\
\text { damage local specificities and natural values }\end{array}$ & ST & high \\
\hline $\begin{array}{c}\text { Encourage the maintenance and strengthening of traditional } \\
\text { activities capable of supporting the conservation of natural and } \\
\text { semi-natural habitats }\end{array}$ & ST & high \\
\hline $\begin{array}{l}\text { Training of administrative and technical staff of those involved in } \\
\text { the management of the site, on specific issues related to the } \\
\text { specificities and needs of management of the Natura } 2000 \text { site }\end{array}$ & ST & high \\
\hline $\begin{array}{c}\text { Information and awareness of users aimed at the prevention of } \\
\text { criticalities and threats }\end{array}$ & ST & high \\
\hline $\begin{array}{l}\text { Improving the level of biodiversity at the local level, good } \\
\text { conservation conditions and the representativeness of habitats }\end{array}$ & LT & high \\
\hline $\begin{array}{l}\text { Mitigation and control of ongoing and potential critical processes } \\
\text { that affect the qualitative and quantitative degradation of habitats, } \\
\text { wildlife and species }\end{array}$ & ST & medium \\
\hline $\begin{array}{l}\text { Providing employment and income opportunities to the local } \\
\text { population through sustainable activities }\end{array}$ & ST & medium \\
\hline $\begin{array}{l}\text { Organization and institutional and operational coordination of } \\
\text { plans, programmes and projects for the uniform and organic } \\
\text { management of sites }\end{array}$ & ST & high \\
\hline $\begin{array}{c}\text { Prevention and control of pressure factors affecting habitats and } \\
\text { species }\end{array}$ & ST & high \\
\hline $\begin{array}{l}\text { Prevention and control of the hydro-geological risk conditions of } \\
\text { the sector according to models compatible with the protection of } \\
\text { the ecological and landscape values of the site }\end{array}$ & ST & high \\
\hline $\begin{array}{l}\text { Promotion of economic activities compatible with the local } \\
\text { specificities and environmental characteristics of the site }\end{array}$ & ST & medium \\
\hline $\begin{array}{c}\text { Promotion of cultivation practices and soil management capable of } \\
\text { enhancing production and preserving natural balance }\end{array}$ & ST & high \\
\hline $\begin{array}{c}\text { Recovery and requalification of degraded areas through the } \\
\text { removal of the causes of criticality }\end{array}$ & ST & high \\
\hline Renaturalisation of plant cover using native species & ST & high \\
\hline $\begin{array}{c}\text { Estimation of the size and distribution of the population of } \\
\text { Quercino in the territory of the site }\end{array}$ & ST & high \\
\hline $\begin{array}{c}\text { Estimation of the size and distribution of the population of Testudo } \\
\text { hermanni in the territory of the site }\end{array}$ & ST & high \\
\hline $\begin{array}{l}\text { Development of appropriate skills and skills to support the } \\
\text { management and exploitation of environmental resources }\end{array}$ & ST & high \\
\hline Protection of pollinating insect species & ST & high \\
\hline $\begin{array}{l}\text { Protection and enhancement of animal biodiversity, good } \\
\text { conservation conditions with increased reproductive sites }\end{array}$ & LT & high \\
\hline
\end{tabular}




\section{Appendix B}

Table A2. Monitoring and research actions: Management habitat: MANAG_HAB [145].

\begin{tabular}{|c|c|c|c|}
\hline Action Code & Action & $\begin{array}{l}\text { Timing } \\
\text { (years) }\end{array}$ & $\begin{array}{l}\text { Estimated } \\
\text { Costs (EUR } \\
\text { /year) }\end{array}$ \\
\hline MANG_HAB_09 & $\begin{array}{c}\text { Monitoring and/or research } \\
\text { programmes_-Study of evolutionary } \\
\text { dynamics }\end{array}$ & 3 & 40,000 \\
\hline MANAG_HAB_21 & $\begin{array}{l}\text { Census of populations and reproductive sites } \\
\text { of amphibian species aimed at estimating } \\
\text { their conservation status with identification of } \\
\text { critical factors and the assessment of the } \\
\text { effectiveness of measures for the protection } \\
\text { and conservation of the same }\end{array}$ & 5 & 6000 \\
\hline MANAG_HAB_25 & Monitoring of bird life & 5 & 15,000 \\
\hline MANAG_HAB_27 & $\begin{array}{l}\text { Update of the survey framework on } \\
\text { conservation surveying entomofauna }\end{array}$ & 3 & 2000 \\
\hline MANAG_HAB_28 & $\begin{array}{l}\text { Implementation of annual wildlife monitoring } \\
\text { in general }\end{array}$ & 5 & 15,000 \\
\hline MANAG_HAB_96 & $\begin{array}{c}\text { Estimation of the size and seasonal pattern of } \\
\text { the population of Quercino (Eliomys } \\
\text { quercinus) }\end{array}$ & 5 & 15,000 \\
\hline MANAG_HAB_98 & $\begin{array}{l}\text { Hermann Tortoise population monitoring } \\
\text { (Testudo hermanni) }\end{array}$ & 5 & 11,000 \\
\hline
\end{tabular}

Table A3. Management and conservation of existing habitats and species: Management habitat: MANAG_HAB [145].

\begin{tabular}{cccc}
\hline Action Code & Action & $\begin{array}{c}\text { Timing } \\
\text { (years) }\end{array}$ & $\begin{array}{c}\text { Estimated } \\
\text { Costs (EUR } \\
\text { /year) }\end{array}$ \\
\hline MANAG_HAB_04 & Eradication of alien pests & 3 & 60,000 \\
\hline MANAG_HAB_05 & Surveillance service (training of personnel) & 0.5 & 8000 \\
\hline MANAG_HAB_09 & $\begin{array}{c}\text { Monitoring and/or research } \\
\text { programmes—volutionary dynamic studies }\end{array}$ & 3 & 40,000 \\
\hline MANAG_HAB_117 & Regulation of cultivation practices & 1 & 2000 \\
\hline MANAG_HAB_118 & $\begin{array}{c}\text { Coordination between Management Plan and } \\
\text { Regional Forestry Plan }\end{array}$ & 0.5 & 2000 \\
\hline MANAG_HAB_119 & $\begin{array}{c}\text { Determination of the forestry potential of the } \\
\text { site }\end{array}$ & 0.66 & 8000 \\
\hline MANAG_HAB_121 & $\begin{array}{c}\text { Study for the sustainable management of } \\
\text { areas of forest interest }\end{array}$ & 0.5 & 25,000 \\
\hline MANAG_HAB_123 & $\begin{array}{c}\text { Detailed study of the hazardous and } \\
\text { hydrogeological risk conditions present in the } \\
\text { site and definition of management strategies }\end{array}$ & 0.5 & 160,000 \\
\hline MANAG_HAB_16 & Creation of micro-areas “sanctuary" & 1 & 800,000 \\
\hline MANAG_HAB_18 & Fire prevention and control & 0.5 & 15,000 \\
\hline MANAG_HAB_19 & Training of professionals in the SIC & 0.5 & 20,000 \\
\hline & $\quad$ & &
\end{tabular}


Table A3. Cont.

\begin{tabular}{|c|c|c|c|}
\hline Action Code & Action & $\begin{array}{l}\text { Timing } \\
\text { (years) }\end{array}$ & $\begin{array}{c}\text { Estimated } \\
\text { Costs (EUR } \\
\text { /year) }\end{array}$ \\
\hline MANAG_HAB_21 & $\begin{array}{l}\text { Census of populations and reproductive sites } \\
\text { of amphibian species aimed at estimating } \\
\text { their conservation status with identification of } \\
\text { critical factors and the assessment of the } \\
\text { effectiveness of protection and conservation } \\
\text { measures themselves }\end{array}$ & 5 & 6000 \\
\hline MANAG_HAB_25 & Monitoring of bird life & 5 & 15,000 \\
\hline MANAG_HAB_27 & Updating the framework & 3 & 15,000 \\
\hline MANAG_HAB_28 & Implementation of annual wildlife monitoring & 5 & 15,000 \\
\hline MANAG_HAB_32 & $\begin{array}{l}\text { Organization of training courses for nature } \\
\text { guides }\end{array}$ & 2 & 90,000 \\
\hline MANAG_HAB_57 & $\begin{array}{l}\text { Guidelines for the best definition of the } \\
\text { Impact Assessment procedure }\end{array}$ & & 10,000 \\
\hline MANAG_HAB_64 & Regulation of uses and activities & 0.5 & 6000 \\
\hline MANAG_HAB_72 & $\begin{array}{c}\text { Collection and conservation of germplasm of } \\
\text { significant botanical species }\end{array}$ & 2 & 60,000 \\
\hline MANAG_HAB_89 & $\begin{array}{l}\text { Recovery of areas of high natural interest } \\
\text { covered by fire }\end{array}$ & 2 & 500,000 \\
\hline MANAG_HAB_97 & $\begin{array}{l}\text { Census of the critical points gravitating on the } \\
\text { site }\end{array}$ & 1 & 30,000 \\
\hline MANAG_HAB_98 & $\begin{array}{l}\text { Monitoring of the Hermann Tortoise } \\
\text { population (Testudo hermanni) }\end{array}$ & 5 & 11,000 \\
\hline
\end{tabular}

Table A4. Upgrading/restoring ecological integrity: Requalification of habitats: REQ_HAB [145].

\begin{tabular}{cccc}
\hline Action Code & Action & $\begin{array}{c}\text { Timing } \\
\text { (years) }\end{array}$ & $\begin{array}{c}\text { Estimated } \\
\text { Costs (EUR } \\
\text { /year) }\end{array}$ \\
\hline REQ_HAB_08 & Remediation of polluted areas & 0.25 & 30,000 \\
\hline REQ_HAB_13 & $\begin{array}{c}\text { Protection, recovery and increase of } \\
\text { amphibian reproductive sites }\end{array}$ & 5 & 40,000 \\
\hline REQ_HAB_14 & $\begin{array}{c}\text { Resurgences in enclosed areas and other } \\
\text { residual spaces aimed at increasing } \\
\text { populations of pollinating insects }\end{array}$ & 5 & 15,000 \\
\hline REQ_HAB_31 & $\begin{array}{c}\text { Measures for the renaturalisation of } \\
\text { allochthonous tree plantings }\end{array}$ & 10 & 400,000 \\
\hline
\end{tabular}

Table A5. Maintenance and restoration of the traditional agricultural landscape: Recover the traditional agricultural landscape: REC_TAL [145].

\begin{tabular}{clcc}
\hline Action Code & Action & $\begin{array}{c}\text { Timing } \\
\text { (years) }\end{array}$ & $\begin{array}{c}\text { Estimated } \\
\text { Costs (EUR } \\
\text { /year) }\end{array}$ \\
\hline REC_TAL_11 & $\begin{array}{l}\text { Maintenance and restoration of the ecological } \\
\text { value of the traditional agricultural landscape }\end{array}$ & 3 & 80,000 \\
\hline
\end{tabular}


Table A6. Construction of new habitats_New habitats: NEW_HAB [145].

\begin{tabular}{cccc}
\hline Action Code & Action & $\begin{array}{c}\text { Timing } \\
\text { (years) }\end{array}$ & $\begin{array}{c}\text { Estimated } \\
\text { Costs (EUR } \\
\text { /year) }\end{array}$ \\
\hline NEW_HAB_17 & $\begin{array}{c}\text { Resurfacing of degraded vegetation cover and } \\
\text { maintenance of soil erosion }\end{array}$ & 3 & 500,000 \\
\hline
\end{tabular}

Table A7. Use of sites, communication, training and enhancement of sustainable economic activities: Use of sites: USE_SIT [145].

\begin{tabular}{|c|c|c|c|}
\hline Action Code & Action & $\begin{array}{l}\text { Timing } \\
\text { (years) }\end{array}$ & $\begin{array}{l}\text { Estimated } \\
\text { Costs (EUR } \\
\text { /year) }\end{array}$ \\
\hline USE_SIT_06 & $\begin{array}{l}\text { Awareness-raising actions on the ecological } \\
\text { and management needs of Natura } 2000 \\
\text { specificities }\end{array}$ & 2 & 60,000 \\
\hline USE_SIT_09 & $\begin{array}{l}\text { Encouraging the development of organic } \\
\text { farming practices-door opening }\end{array}$ & 3 & 30,000 \\
\hline USE _SIT_10 & $\begin{array}{l}\text { Encouraging the development of organic } \\
\text { farming practices-economic incentives }\end{array}$ & 3 & 150,000 \\
\hline USE_SIT_13 & Widespread hotel & $0.5-1$ & 60,000 \\
\hline USE_SIT_46 & $\begin{array}{l}\text { Promotion of good sustainability practices } \\
\text { among agricultural producers }\end{array}$ & 1 & 10,000 \\
\hline FRU_SIT_51 & $\begin{array}{c}\text { Encouragement to the creation of agritourism } \\
\text { and reception points }\end{array}$ & 5 & 400,000 \\
\hline USE_SIT_52 & $\begin{array}{l}\text { Construction of an environmental education } \\
\text { centre and reception points }\end{array}$ & 1 & 300,000 \\
\hline USE_SIT_53 & $\begin{array}{c}\text { Completion of panels and tables and } \\
\text { information points on the Natura } 2000 \\
\text { Network }\end{array}$ & 2 & 300,000 \\
\hline USE_SIT_65 & $\begin{array}{c}\text { Information website on recreational and } \\
\text { educational activities in respect of nature and } \\
\text { local culture }\end{array}$ & 0.5 & 50,000 \\
\hline USE_SIT_132 & $\begin{array}{l}\text { Interpretive design and installation of the } \\
\text { entrance hall of the SIC "Timpa di Acireale" }\end{array}$ & 1 & 18,400 \\
\hline USE_SIT_138 & $\begin{array}{c}\text { Upgrading and rationalisation of the existing } \\
\text { track network }\end{array}$ & 1 & 500,000 \\
\hline
\end{tabular}




\section{Appendix C}

Table A8. The estimated costs of the actions set out in the Management Plan [145].

\begin{tabular}{|c|c|c|c|c|c|c|c|c|c|c|c|}
\hline Action Code & 2009 & 2010 & 2011 & 2012 & 2013 & 2014 & 2015 & 2016 & 2017 & 2018 & $\begin{array}{c}\text { Total } \\
\text { Expenditure } \\
\text { per Action }\end{array}$ \\
\hline & EUR & EUR & EUR & EUR & EUR & EUR & EUR & EUR & EUR & EUR & EUR \\
\hline GES HAB 04 & 60,000 & 60,000 & 60,000 & & & & & & & & 180,000 \\
\hline GES_HAB_05 & 8000 & & & & & & & & & & 8000 \\
\hline GES_HAB_09 & 40,000 & 40,000 & 40,000 & & & & & & & & 120,000 \\
\hline GES_HAB_16 & 800,000 & & & & & & & & & & 800,000 \\
\hline GES_HAB_18 & 15,000 & & & & & & & & & & 15,000 \\
\hline GES HAB 19 & 20,000 & & & & & & & & & & 20,000 \\
\hline GES_HAB_21 & 6000 & 6000 & 6000 & 6000 & 6000 & & & & & & 30,000 \\
\hline GES_HAB_25 & 15,000 & 15,000 & 15,000 & 15,000 & 15,000 & & & & & & 75,000 \\
\hline GES_HAB_27 & 8000 & & & & & & & & & & 8000 \\
\hline GES HAB 28 & 2000 & 2000 & 2000 & & & & & & & & 6000 \\
\hline GES_HAB_28 & 15,000 & 15,000 & 15,000 & 15,000 & 15,000 & & & & & & 75,000 \\
\hline GES_HAB_32 & & 90,000 & & & & & & & & & 90,000 \\
\hline GES_HAB_57 & 10,000 & & & & & & & & & & 10,000 \\
\hline GES_HAB_64 & 10,000 & & & & & & & & & & 10,000 \\
\hline GES HAB 72 & & 60,000 & & & & & & & & & 60,000 \\
\hline GES_HAB_89 & & 500,000 & & & & & & & & & 500,000 \\
\hline GES_HAB_96 & 15,000 & 15,000 & 15,000 & 15,000 & 15,000 & & & & & & 75,000 \\
\hline GES_HAB_97 & 30,000 & & & & & & & & & & 30,000 \\
\hline GES_HAB_98 & 11,000 & 11,000 & 11,000 & 11,000 & 11,000 & & & & & & 55,000 \\
\hline GES_HAB_117 & 2000 & & & & & & & & & & 2000 \\
\hline GES_HAB_118 & 2000 & & & & & & & & & & 2000 \\
\hline GES HAB 119 & 8000 & & & & & & & & & & 8000 \\
\hline GES_HAB_121 & 25,000 & & & & & & & & & & 25,000 \\
\hline GES HAB 123 & 160,000 & & & & & & & & & & 160,000 \\
\hline RIQ_HAB_08 & 30,000 & & & & & & & & & & 30,000 \\
\hline RIQ_HAB_13 & 40,000 & 40,000 & 40,000 & 40,000 & 40,000 & & & & & & 200,000 \\
\hline RIQ_HAB_14 & 15,000 & 15,000 & 15,000 & 15,000 & 15,000 & & & & & & 75,000 \\
\hline RIQ_HAB_31 & 400,000 & 400,000 & 400,000 & 400,000 & 400,000 & 400,000 & 400,000 & 400,000 & 400,000 & 400,000 & $4,000,000$ \\
\hline REC_PAT_11 & 80,000 & 80,000 & 80,000 & & & & & & & & 240,000 \\
\hline NUO_HAB_17 & & & 500,000 & & & & & & & & 500,000 \\
\hline $\begin{array}{c}\text { Annual total } \\
\text { spent }\end{array}$ & $1,827,000$ & $1,349,000$ & $1,199,000$ & 517,000 & 517,000 & 400,000 & 400,000 & 400,000 & 400,000 & 400,000 & $7,409,000$ \\
\hline
\end{tabular}

\section{References}

1. Schneider, S.H. The greenhouse effect: Science and policy. Science 1989, 243, 771-781. [CrossRef]

2. Ayres, R.U.; Walter, J. The greenhouse effects: Damages, costs and abatement. Environ. Resour. Econ. 1991, 1, 237-270. [CrossRef]

3. Pearce, D.W. The Secondary Benefits of Greenhouse Gas Control; CSERGE Working Paper 92-12; CSERGE; University of East Anglia: Norwich, UK; University College: London, UK, 1992.

4. Intergovernmental Panel on Climate Change. Climate Change 1995: Economic and Social Dimensions of Climate Change. Contribution of the Working Group III to the Second Assessment Report of the Intergovernmental Panel on Climate Change; Cambridge University Press: Cambridge, UK, 1995; Available online: https://archive.ipcc.ch/pdf/climate-changes-1995/ipcc-2nd-assessment/2ndassessment-en.pdf (accessed on 2 March 2019).

5. Intergovernmental Panel on Climate Change. Climate Change 2001: Mitigation, Contribution of Working Group III to the Third Assessment Report of the Intergovernmental Panel on Climate Change; Cambridge University Press: Cambridge, UK, 2001.

6. Intergovernmental Panel on Climate Change. Climate Change 2007: Mitigation, Contribution of Working Group III to the Fourth Assessment Report of the Intergovernmental Panel on Climate Change; Cambridge University Press: Cambridge, UK, 2007.

7. Intergovernmental Panel on Climate Change. Climate Change 2014: Mitigation, Contribution of Working Group III to the Fifth Assessment Report of the Intergovernmental Panel on Climate Change; Cambridge University Press: Cambridge, UK, 2014.

8. Intergovernmental Panel on Climate Change. Climate Change 2011. In Climate Change 2007: Mitigation of Climate Change. Contribution of Working Group III to the Fourth Assessment Report of the Intergovernmental Panel on Climate Change; Cambridge University Press: Cambridge, UK, 2011.

9. ADB Rethinking Transport and Climate Change. James Leather and the Clean Air Initiative for Asian Cities Center. Sustainable Development Working Paper Series. Team No. 10, Asian Development Bank, December 2009. Available online: https://www. adb.org/sites/default/files/publication/28489/adb-wp10-rethinking-transport-climate-change (accessed on 4 March 2019).

10. European Parliament; The Council of The European Union. Directive 2009/147/EC of 30 November 2009 on the Conservation of Wild Birds; Birds Directive (Codified Version of Directive 79/409/EEC as Amended); European Parliament: Brussels, Belgium, 2009. 
11. Council of The European Communities. Directive 92/43/EEC of 21 May 1992 on the Conservation of Natural Habitats and of Wild Fauna and Flora; Habitats Directive (Also Available the Consolidated Version of 1 January 2007 with the Latest Updates of the Annexes); Council of The European Communities: Brussels, Belgium, 2009.

12. Council of The European Union. Directive 1999/22/EC of 29 March 1999 on the Keeping of Wild Animals in Zoos; Zoos Directive; Council of The European Union: Brussels, Belgium, 1999.

13. European Parliament; The Council of The European Union. Regulation (EU) No 1143/2014 of 22 October 2014 on the Prevention and Management of the Introduction and Spread of Invasive Alien Species; Regulation on Invasive Alien Species; European Parliament: Brussels, Belgium, 2014.

14. European Parliament; The Council of The European Union. Trade in Seal Products: Regulation (EC) No 1007/2009 of 16 September 2009 on Trade in Seal Products; Text with EEA Relevance; European Parliament: Brussels, Belgium, 2009.

15. Council of The European Communities. Directive 83/129/EEC of 28 March 1983 Concerning the Importation into Member States of Skins of Certain Seal Pups and Products Derived Therefrom; Seal Pups Directive; Council of The European Communities: Brussels, Belgium, 1983.

16. Council of The European Communities. Regulation (EEC) No 3254/91 of 4 November 1991 Prohibiting the Use of Leghold Traps in the Community and the Introduction into the Community of Pelts and Manufactured Goods of Certain Wild Animal Species Originating in Countries Which Catch Them by Means of Leghold Traps or Trapping Methods Which Do Not Meet International Humane Trapping Standard; Leghold Traps Regulation; Council of The European Communities: Brussels, Belgium, 1991.

17. European Commission. COM (2019) 640 Final. Communication from the Commission to the European Parliament, the European Council, the Council, the European Economic and Social Committee and the Committee of the Regions; The European Green Deal; European Commission: Brussels, Belgium, 2019.

18. Legge 16 Gennaio 2019, n. 8. Ratifica ed Esecuzione dell'Accordo Relativo alla Protezione dell'Ambiente Marino e Costiero di Una Zona del Mare Mediterraneo (Accordo RAMOGE), tra Italia, Francia e Principato di Monaco, Fatto a Monaco il 10 Maggio 1976 ed Emendato a Monaco il 27 novembre 2003. (19G00013) (OJ No 32, 07-02-2019). Rome, Italy, 2019. Available online: https: / / www.normattiva.it/uri-res/N2Ls?urn:nir:stato:legge:2019-01-16;8!vig= (accessed on 4 March 2019).

19. Decreto Legislativo 13 Ottobre 2010, n. 190. Attuazione della Direttiva 2008/56/CE che Istituisce un Quadro per l'Azione Comunitaria nel Campo della Politica per l'Ambiente Marino. (10G0212) (OJ No 270, 18-11-2010). Rome, Italy, 2010. Available online: https: / / www.normattiva.it/uri-res/N2Ls?urn:nir:stato:decreto.legislativo:2010-10-13;190!vig= (accessed on 20 March 2019).

20. Legge 8 Febbraio 2006, n. 61. Istituzione di Zone di Protezione Ecologica oltre il Limite Esterno del Mare Territoriale. (OJ No 52, 1 03-03-2006). Rome, Italy, 2006. Available online: https:/ / www.normattiva.it/uri-res/N2Ls?urn:nir:stato:legge:2006-02-08;61!vig= (accessed on 20 March 2019).

21. Decreto del Presidente della Repubblica 12 Marzo 2003, n. 120. Regolamento Recante Modifiche ed Integrazioni al Decreto del Presidente della Repubblica 8 Settembre 1997, n. 357, Concernente Attuazione della Direttiva 92/43/CEE Relativa alla Conservazione degli Habitat Naturali e Seminaturali, Nonché della Llora e della Fauna Selvatiche. (OJ No 124, 30-05-2003). Rome, Italy, 2003. Available online: https:/ / www.normattiva.it/uri-res/N2Ls?urn:nir:stato:decreto.del.presidente.della.repubblica: 2003-03-12;120!vig= (accessed on 10 March 2019).

22. Legge 27 Maggio 1999, n. 175. Ratifica ed Esecuzione dell'Atto Finale della Conferenza dei Plenipotenziari sulla Convenzione per la Protezione del Mar Mediterraneo dall'Inquinamento, con Relativi Protocolli, Tenutasi a Barcellona il 9 e 10 Giugno 1995. (OJ No 14, 17-06-1999-Supp. Ordinary No 116). Rome, Italy, 1999. Available online: https:/ / www.normattiva.it/uri-res/N2Ls?urn: nir:stato:legge:1999-05-27;175!vig= (accessed on 10 March 2019).

23. Decreto del Presidente della Repubblica 8 Settembre 1997, n. 357. Regolamento Recante Attuazione della Direttiva 92/43/CEE Relativa alla Conservazione degli Habitat Naturali e Seminaturali, Nonché della Flora e della Fauna Selvatiche. (OJ No 248, 23-10-1997-Supp. Ordinary No 219). Rome, Italy, 1997. Available online: https:/ / www.normattiva.it/uri-res/N2Ls?urn:nir: stato:decreto.del.presidente.della.repubblica:1997-09-08;357!vig= (accessed on 2 March 2019).

24. Legge 14 Febbraio 1994, n. 124. Ratifica ed Esecuzione della Convenzione sulla Biodiversità, con Annessi, Fatta a Rio de Janeiro il 5 Giugno 1992. (OJ No 44, 23-02-1994-Supp. Ordinary No 33). Rome, Italy, 1994. Available online: https: / / www.normattiva.it/ uri-res/N2Ls?urn:nir:stato:legge:1994-02-14;124!vig= (accessed on 10 March 2019).

25. Legge 6 Dicembre 1991, n. 394. Legge Quadro sulle Aree Protette. (OJ No 292, 13-12-1991—Supp. Ordinary No 83). Italy, 1991. Available online: https:/ /www.normattiva.it/uri-res/N2Ls?urn:nir:stato:legge:1991-12-06;394!vig= (accessed on 10 March 2019).

26. Legge 8 Luglio 1986, n. 349. Istituzione del Ministero dell'Ambiente e Norme in Materia di Danno Ambientale. (OJ No 162, 15-07-1986-Supp. Ordinary No 59). Rome, Italy, 1986. Available online: https:/ / www.normattiva.it/uri-res/N2Ls?urn:nir:stato: legge:1986-07-08;349!vig= (accessed on 10 March 2019).

27. Legge 25 Gennaio 1983, n. 42. Ratifica ed Esecuzione della Convenzione sulla Conservazione delle Specie Migratorie Appartenenti alla Fauna Selvatica, con Allegati, Adottata a Bonn il 23 Giugno 1979. (OJ No 48, 18-02-1983). Rome, Italy, 1983. Available online: https:/ / www.normattiva.it/uri-res/N2Ls?urn:nir:stato:legge:1983-01-25;42!vig= (accessed on 10 March 2019).

28. Legge 31 Dicembre 1982, n. 979. Disposizioni per la Difesa del Mare. (OJ No 16, 18-01-1983). Rome, Italy, 1983. Available online: https:/ / www.normattiva.it/uri-res/N2Ls?urn:nir:stato:legge:1982-12-31;979!vig= (accessed on 10 March 2019). 
29. Legge 5 Agosto 1981, n. 503. Ratifica ed Esecuzione della Convenzione Relativa alla Conservazione della Vita Selvatica e dell'Ambiente Naturale in Europa, con Allegati, Adottata a Berna il 19 Settembre 1979. (OJ No 250, 11-9-1981). Italy, 1981. Available online: https:/ / www.normattiva.it/uri-res/N2Ls?urn:nir:stato:legge:1981-08-05;503!vig= (accessed on 2 March 2019).

30. Legge 19 Dicembre 1975, n. 874. Ratifica ed Esecuzione della Convenzione sul Commercio Internazionale delle Specie Animali e Vegetali in via di Estinzione, Firmata a Washington il 3 Marzo 1973. (OJ No 49, 24-2-1976). Rome, Italy, 1975. Available online: https:/ / www.normattiva.it/uri-res/N2Ls?urn:nir:stato:legge:1975-12-19;874!vig= (accessed on 2 March 2019).

31. Decreto del Presidente della Repubblica 5 Luglio 2019, n. 102. Regolamento Recante Ulteriori Modifiche dell'Articolo 12 del Decreto del Presidente della Repubblica 8 Settembre 1997, n. 357, Concernente Attuazione della Direttiva 92/43/CEE Relativa alla Conservazione degli Habitat Naturali e Seminaturali, Nonché della Flora e della Fauna Selvatiche. (19G00108) (OJ No 208, 05-09-2019). Rome, Italy, 2019. Available online: https:/ / www.normattiva.it/uri-res/N2Ls?urn:nir:stato:decreto.del.presidente. della.repubblica:2019-07-05;102! vig= (accessed on 10 March 2019).

32. Legge 6 Febbraio 2006, n. 66. Adesione della Repubblica Italiana all'Accordo sulla Conservazione degli Uccelli Acquatici Migratori dell'Africa-EURASIA, con Allegati e Tabelle, Fatto a L'Aja il 15 Agosto 1996. (OJ No.53, 04-03-2006-Supp. Ordinary No 51). Rome, Italy, 2006. Available online: https: / / www.normattiva.it/uri-res/N2Ls?urn:nir:stato:legge:2006-02-06;66!vig= (accessed on 20 April 2020).

33. Legge 27 Maggio 2005, n. 104. Adesione della Repubblica Italiana all'Accordo sulla Conservazione delle Popolazioni di Pipistrelli Europei (EUROBATS), con Emendamenti, Fatto a Londra il 4 Dicembre 1991, e sua Esecuzione. (OJ No 138, 16-06-2005Supp. Ordinary No 109). Rome, Italy, 2005. Available online: https:/ /www.normattiva.it/uri-res/N2Ls?urn:nir:stato:legge: 2005-05-27;104! vig= (accessed on 15 March 2019).

34. Legge 14 Ottobre 1999, n. 403. Ratifica ed Esecuzione della Convenzione per la Protezione delle Alpi, con Allegati e Processo Verbale di Modifica del 6 Aprile 1993, Fatta a Salisburgo il 7 Novembre 1991. (OJ No 262, 08-11-1999—Supp. Ordinary No 194). Rome, Italy, 1999. Available online: https:/ / www.normattiva.it/uri-res/N2Ls?urn:nir:stato:legge:1999-10-14;403!vig= (accessed on 10 March 2019).

35. Legge 11 Febbraio 1992, n. 157. Norme per la Protezione della Fauna Selvatica Omeoterma e per il Prelievo Venatorio. (OJ No 46, 25-02-1992-Supp. Ordinary No 41). Rome, Italy, 1992. Available online: https:/ / www.normattiva.it/uri-res/N2Ls?urn:nir:stato: legge:1992-02-11;157!vig= (accessed on 15 April 2019).

36. Legge 6 Aprile 1977, n. 184. Ratifica ed Esecuzione della Convenzione sulla Protezione del Patrimonio Culturale e Naturale Mondiale, Firmata a Parigi il 23 Novembre 1972. (OJ No 129, 13-05-1977). Rome, Italy, 1977. Available online: https: / www. normattiva.it/uri-res/N2Ls?urn:nir:stato:legge:1977-04-06;184!vig= (accessed on 10 March 2019).

37. Decreto del Presidente della Repubblica 13 Marzo 1976, n. 448. Esecuzione della Convenzione Relativa alle Zone Umide d'Importanza Internazionale, Soprattutto come Habitat degli Uccelli Acquatici, Firmata a Ramsar il 2 Febbraio 1971. (OJ No 173, 03-07-1976). Rome, Italy, 1976. Available online: https:/ / www.normattiva.it/uri-res/N2Ls?urn:nir:stato:decreto.del.presidente. della.repubblica:1976-03-13;448!vig= (accessed on 2 March 2019).

38. Decreto Legislativo 3 Aprile 2006, n. 152 Norme in Materia Ambientale. (OJ No 88, 14-04-2006-Supp. Ordinary No 96). Rome, Italy, 2006. Available online: https:/ / www.normattiva.it/uri-res/N2Ls?urn:nir:stato:decreto.legislativo:2006-04-03;152!vig= (accessed on 10 March 2019).

39. Legge 23 Marzo 2001, n. 93. Disposizioni in Campo Ambientale. (OJ No 79, 04-04-2001). Italy, 2001. Available online: https:/ / www.normattiva.it/uri-res/N2Ls?urn:nir:stato:legge:2001-03-23;93!vig= (accessed on 10 March 2019).

40. Legge 8 Ottobre 1997, n. 344. Disposizioni per lo Sviluppo e la Qualificazione degli Interventi e dell'Occupazione in Campo Ambientale. (OJ No 239,13-10-1997). Rome, Italy, 1997. Available online: https:/ / www.normattiva.it/uri-res/N2Ls?urn:nir:stato: legge:1997-10-08;344!vig= (accessed on 5 April 2020).

41. Decreto Legislativo 3 Aprile 2018, n. 34. Testo Unico in Materia di Foreste e Filiere Forestali. (18G00060) (OJ No 92, 20-04-2018). Rome, Italy, 2018. Available online: https:/ /www.normattiva.it/uri-res/N2Ls?urn:nir:stato:decreto.legislativo:2018-04-03;34!vig= (accessed on 5 April 2020).

42. Decreto Legislativo 10 Novembre 2003, N. 386 Attuazione della Direttiva 1999/105/CE Relativa alla Commercializzazione dei Materiali Forestali di Moltiplicazione. (OJ No 23, 29-1-2004-Supp. Ordinary No 14). Italy, 2003. Available online: https:/ / www.normattiva.it/uri-res/N2Ls?urn:nir:stato:decreto.legislativo:2003-11-10;386!vig= (accessed on 5 April 2020).

43. Regio Decreto-Legge 30 Dicembre 1923, n. 3267. Riordinamento e Riforma della Legislazione in Materia di Boschi e di Terreni Montani. (023U3267) (OJ No 117, 17-05-1924). Rome, Italy, 1924. Available online: https:/ /www.normattiva.it/uri-res/N2Ls?urn: nir:stato:regio.decreto.legge:1923-12-30;3267!vig= (accessed on 10 March 2019).

44. Legge 9 Novembre 2012, n. 196. Ratifica ed Esecuzione del Protocollo di Attuazione della Convenzione per la Protezione delle Alpi del 1991 nell'Ambito dei Trasporti, Fatto a Lucerna il 31 Ottobre 2000. (12G0217) (OJ No 271, 20-11-2012). Rome, Italy, 2012. Available online: https:/ / www.normattiva.it/uri-res/N2Ls?urn:nir:stato:legge:2012-11-09;196!vig= (accessed on 15 December 2020).

45. Legge 5 Aprile 2012, n. 50 Ratifica ed Esecuzione dei Protocolli di Attuazione della Convenzione Internazionale per la Protezione delle Alpi, con Annessi, Fatta a Salisburgo il 7 Novembre 1991. (12G0070) (OJ No 103, 04-05-2012—Supp. Ordinary No 89). Rome, Italy, 2012. Available online: https:/ / www.normattiva.it/uri-res/N2Ls?urn:nir:stato:legge:2012-04-05;50!vig= (accessed on 15 December 2020). 
46. Decreto 27 Aprile 2010. Approvazione dello Schema Aggiornato, Relativo al VI Elenco Ufficiale delle Aree Protette, ai Sensi del Combinato Disposto dell'Art. 3, Comma 4, Lettera c), della Legge 6 Dicembre 1994, n. 394 e dall'Articolo 7, Comma 1, del Decreto Legislativo 28 Agosto 1997, n. 281. (OJ No 125, 31-05-2010-Supp. Ordinary No 115). Rome, Italy, 2010. Available online: https:/ /www.gazzettaufficiale.it/eli/id/2010/05/31/10A06507/sg (accessed on 15 December 2020).

47. Decreto Legislativo 26 Marzo 2008, n. 63. Ulteriori Disposizioni Integrative e Correttive del Decreto Legislativo 22 Gennaio 2004, n. 42, in Relazione al Paesaggio. (OJ No 84, 09-04-2008). Rome, Italy, 2008. Available online: https://www.normattiva.it/uri-res/ N2Ls?urn:nir:stato:decreto.legislativo:2008-03-26;63!vig= (accessed on 15 December 2020).

48. Legge 9 Gennaio 2006, n. 14. Ratifica ed Esecuzione della Convenzione Europea sul Paesaggio, Fatta a Firenze il 20 Ottobre 2000. (OJ No 16, 20-01-2006-Supp. Ordinary No 16). Rome, Italy, 2006. Available online: https:/ / www.normattiva.it/uri-res/N2Ls? urn:nir:stato:legge:2006-01-09;14!vig= (accessed on 15 December 2020).

49. Decreto Legislativo 24 Marzo 2006, n. 157. Disposizioni Correttive ed Integrative al Decreto Legislativo 22 Gennaio 2004, n. 42, in Relazione al Paesaggio. (OJ No 97, 27-04-2006-Supp. Ordinary No 102). Rome, Italy, 2006. Available online: https:/ / www.normattiva.it/uri-res/N2Ls?urn:nir:stato:decreto.legislativo:2006-03-24;157!vig= (accessed on 15 December 2020).

50. Decreto Legislativo 22 Gennaio 2004, n. 42. Codice dei Beni Culturali e del Paesaggio, ai Sensi dell'Articolo 10 della Legge 6 Luglio 2002, n. 137. (OJ No 45, 24-02-2004-Supp. Ordinary No 28). Rome, Italy, 2004. Available online: https: / / www.normattiva. it/uri-res/N2Ls?urn:nir:stato:decreto.legislativo:2004-01-22;42!vig= (accessed on 15 December 2020).

51. Legge 9 Dicembre 1998, n. 426. Nuovi Interventi in Campo Ambientale. (OJ No 291 del 14-12-1998). Italy, 1998. Available online: https: / / www.normattiva.it/uri-res/N2Ls?urn:nir:stato:legge:1998-12-09;426!vig= (accessed on 15 December 2020).

52. Legge 31 Gennaio 1994, n. 97. Nuove Disposizioni per le Zone Montane. (OJ No 32, 09-02-1994—Supp. Ordinary No 24). Rome, Italy, 1994. Available online: https:/ / www.normattiva.it/uri-res/N2Ls?urn:nir:stato:legge:1994-01-31;97!vig= (accessed on 15 December 2020).

53. Decreto Legislativo 17 Ottobre 2016, n. 201. Attuazione della Direttiva 2014/89/UE che Istituisce un Quadro per la Pianificazione dello Spazio Marittimo. (16G00215) (OJ No 260, 07-11-2016). Rome, Italy, 2016. Available online: https:/ /www.normattiva.it/ urires/N2Ls?urn:nir:stato:decreto.legislativo:2016-10-17;201!vig= (accessed on 15 December 2020).

54. Decreto del Presidente della Repubblica 27 Ottobre 2011, n. 209. Regolamento Recante Istituzione di Zone di Protezione Ecologica del Mediterraneo Nord-Occidentale, del Mar Ligure e del Mar Tirreno. (11G0252) (OJ No 293, 17-12-2011). Italy, 2011. Available online: https:/ / www.normattiva.it/uri-res/N2Ls?urn:nir:stato:decreto.del.presidente.della.repubblica:2011-10-27;2 09! vig= (accessed on 15 December 2020).

55. Legge 10 Febbraio 2005, n. 27. Ratifica ed Esecuzione dell'Accordo sulla Conservazione dei Cetacei del Mar Nero, del Mediterraneo e dell'Area Atlantica Contigua, con Annessi ed Atto Finale, Fatto a Monaco il 24 Novembre 1996. (OJ No 51, 03-03-2005Supp. Ordinary No 27). Rome, Italy, 2005. Available online: https://www.normattiva.it/uri-res/N2Ls?urn:nir:stato:legge: 2005-02-10;27! vig= (accessed on 15 December 2020).

56. Legge 11 Ottobre 2001, n. 391. Ratifica ed Esecuzione dell'Accordo Relativo alla Creazione nel Mediterraneo di un Santuario per i Mammiferi Marini, Fatto a Roma il 25 Novembre 1999. (OJ No 253, 30-10-2001). Rome, Italy, 2001. Available online: https: / / www.normattiva.it/uri-res/N2Ls?urn:nir:stato:legge:2001-10-11;391!vig= (accessed on 15 December 2020).

57. Legge 5 Marzo 1985, n. 127. Ratifica ed Esecuzione del Protocollo Relativo alle Aree Specialmente Protette del Mediterraneo, Aperto alla Firma a Ginevra il 3 Aprile 1982. (OJ No 89, 15-04-1985). Italy, 1985. Available online: https: / / www.normattiva.it/ uri-res/N2Ls?urn:nir:stato:legge:1985-03-05;127!vig= (accessed on 15 December 2020).

58. Legge 1 Dicembre 2015, n. 194. Disposizioni per la Tutela e la Valorizzazione della Biodiversità di Interesse Agricolo e Alimentare. (15G00210) (OJ No 288, 11-12-2015). Rome, Italy, 2015. Available online: https:/ / www.normattiva.it/uri-res /N2Ls?urn:nir:stato: legge:2015-12-01;194!vig= (accessed on 15 December 2020).

59. Legge 24 Dicembre 2004, n. 313. Disciplina dell'Apicoltura. (OJ No 306, 31-12-2004). Italy, 2004. Available online: https: / / www.normattiva.it/uri-res/N2Ls?urn:nir:stato:legge:2004-12-24;313!vig= (accessed on 15 December 2020).

60. Legge 28 Dicembre 2015, n. 221. Disposizioni in Materia Ambientale per Promuovere Misure di Green Economy e per il Contenimento dell'Uso Eccessivo di Risorse Naturali. (16G00006) (OJ No 13, 18-01-2016) (Environmental Related). Rome, Italy, 2015. Available online: https:/ / www.normattiva.it/uri-res/N2Ls?urn:nir:stato:legge:2015-12-28;221!vig= (accessed on 15 December 2020).

61. Decreto Legislativo 15 Dicembre 2017, n. 230. Adeguamento della Normativa Nazionale alle Disposizioni del Regolamento (UE) n. 1143/2014 del Parlamento Europeo e del Consiglio del 22 Ottobre 2014, Recante Disposizioni Volte a Prevenire e Gestire l'Introduzione e la Diffusione delle Specie Esotiche Invasive. (18G00012) (OJ No 24, 30-01-2018). Rome, Italy, 2018. Available online: https:/ / www.normattiva.it/uri-res/N2Ls?urn:nir:stato:decreto.legislativo:2017-12-15;230!vig= (accessed on 15 December 2020).

62. Legge 28 Luglio 2016, n. 154. Deleghe al Governo e Ulteriori Disposizioni in Materia di Semplificazione, Razionalizzazione e Competitività dei Settori Agricolo e Agroalimentare, Nonché Sanzioni in Materia di Pesca Illegale. (16G00169) (OJ No 186, 10-08-2016) (Agricultural Related). Rome, Italy, 2016. Available online: https:/ / www.normattiva.it/uri-res/N2Ls?urn:nir:stato: legge:2016-07-28;154!vig= (accessed on 15 December 2020). 
63. Decreto Legislativo 4 Aprile 2006, n. 192. Disposizioni Correttive del Decreto Legislativo 21 Marzo 2005, n. 73, Recante Attuazione della Direttiva 1999/22/CE Relativa alla Custodia degli Animali Selvatici nei Giardini Zoologici. (OJ No 121, 26-05-2006).Rome, Italy, 2006. Available online: https:/ /www.normattiva.it/uri-res/N2Ls?urn:nir:stato:decreto.legislativo:2006-04-04;192!vig= (accessed on 15 December 2020).

64. Decreto Legislativo 21 Marzo 2005, n. 73. Attuazione della Direttiva 1999/22/CE Relativa alla Custodia degli Animali Selvatici nei Giardini Zoologici. (OJ No 100, 02-05-2005). Rome, Italy, 2005. Available online: https:/ /www.normattiva.it/uri-res/N2Ls?urn: nir:stato:decreto.legislativo:2005-03-21;73!vig= (accessed on 15 December 2020).

65. Legge 7 Febbraio 1992, n. 150. Disciplina dei Reati Relativi all'Applicazione in Italia della Convenzione sul Commercio Internazionale delle Specie Animali e Vegetali in via di Estinzione, Firmata a Washington il 3 Marzo 1973, di cui alla Legge 19 Dicembre 1975, n. 874, e del Regolamento (CEE) n. 3626/82, e Successive Modificazioni, Nonché Norme per la Commercializzazione e la Detenzione di Esemplari Vivi di Mammiferi e Rettili che Possono Costituire Pericolo per la Salute e l'Incolumità' Pubblica. (OJ No 44, 22-02-1992). Rome, Italy, 1992. Available online: https://www.normattiva.it/uri-res/N2Ls?urn:nir:stato:legge: 1992-02-07;150!vig= (accessed on 15 December 2020).

66. Giuffrida, S.; Trovato, M.R. A Semiotic Approach to the Landscape Accounting and Assessment. An Application to the Urban-Coastal Areas. In Proceedings of the 8th International Conference on Information and Communication Technologies in Agriculture, Food and Environment, HAICTA 2017, Chania, Crete Island, Greece, 21-24 September 2017; Salampasis, M., Theodoridis, A., Bournaris, T., Eds.; CEUR Workshop Proceedings: Aachen, Germany, 2016; pp. 696-708.

67. Giuffrida, S.; Trovato, M.R.; Giannelli, A. Semiotic-Sociological Textures of Landscape Values. Assessments in Urban-Coastal Areas. Information and Communication Technologies in Modern Agricultural Development. In Proceedings of the 8th International Conference HAICTA 2017, Chania, Crete, Greece, 21-24 September 2017; Salampasis, M., Bournaris, T., Eds.; Springer: Cham, Switzerland, 2019; pp. 35-50.

68. Giuffrida, S.; Trovato, M.R. From the Object to Land. Architectural Design and Economic Valuation in the Multiple Dimensions of the Industrial Estates. Computational Science and Its Applications-ICCSA 2017. In Proceedings of the 17th International Conference, ICCSA 2017, Trieste, Italy, 3-6 July 2017; Borruso, G., Cuzzocrea, A., Apduhan, B.O., Rocha, A.M.A.C., Taniar, D., Misra, S., Gervasi, O., Torre, C.M., Stankova, E., Murgante, B., Eds.; Lecture Notes in Computer Science. Springer: Cham, Switzerland, 2017; pp. 591-606. [CrossRef]

69. Giuffrida, S.; Trovato, M.R.; Falzone, M. The information value for territorial and economic sustainability in the enhancement of the water management process. Computational Science and Its Applications-ICCSA 2017. In Proceedings of the 17th International Conference, ICCSA 2017, Trieste, Italy, 3-6 July 2017; Borruso, G., Cuzzocrea, A., Apduhan, B.O., Rocha, A.M.A.C., Taniar, D., Misra, S., Gervasi, O., Torre, C.M., Stankova, E., Murgante, B., Eds.; Lecture Notes in Computer Science. Springer: Cham, Switzerland, 2017; pp. 575-590. [CrossRef]

70. Giuffrida, S.; Gagliano, F.; Trovato, M.R. Land as Information. A Multidimensional Valuation Approach for Slow Mobility Planning. In Proceedings of the 7th International Conference on Information and Communication Technologies in Agriculture, Food and Environment (HAICTA 2015), Kavala, Greece, 17-20 September 2015; Andreopoulou, Z., Bochtis, D., Eds.; CEUR Workshop Proceedings: Aachen, Germany, 2015; pp. 879-891.

71. Della Spina, L. Scenarios for a sustainable valorisation of cultural landscape as driver of local development. In Proceedings of the 3rd International New Metropolitan Perspectives, Local Knowledge and Innovation Dynamics towards Territory Attractiveness through the Implementation of Horizon/Europe2020/Agenda2030, 2018, Reggio Calabria, Italy, 22-25 May 2018; Bevilacqua, C., Calabro, F., Della Spina, L., Eds.; Smart Innovation, Systems and Technologies. Springer: Cham, Switzerland, 2019 ; pp. 113-122. [CrossRef]

72. Calabrò, F.; Iannone, L.; Pellicanò, R. The historical and environmental heritage for the attractiveness of cities. The case of the umbertine forts of pentimele in reggio calabria, Italy. In Proceedings of the 4th International Symposium on New Metropolitan Perspectives, NMP 2020, Reggio Calabria, Italy, 26-28 May 2020; Bevilacqua, C., Calabro, F., Della Spina, L., Eds.; Smart Innovation, Systems and Technologies. Springer: Cham, Switzerland, 2021; pp. 1990-2004. [CrossRef]

73. Lucrezia, L.; Pérez, Y. Turismo, patrimonio e cultura: Verso un'educazione territoriale. Un caso studio in Galizia (Spagna). Laborest 2020, 21, 18-24.

74. TEEB. The Economics of Ecosystems and Biodiversity. Ecological and Economic Foundations; Kumar, P., Ed.; Earthscan: London, UK; Washington, DC, USA, 2010.

75. TEEB. The Economics of Ecosystems and Biodiversity in National and International Policy Making; Ten Brink, P., Ed.; Earthscan: London, UK; Washington, DC, USA, 2011.

76. Millennium Ecosystem Assessment. Ecosystems and Human Well-Being: Biodiversity Synthesis; World Resources Institute: Washington, DC, USA, 2005.

77. Kettunen, M.; Genovesi, P.; Gollasch, S.; Pagad, S.; Starfinger, U.; Ten Brink, P.; Shine, C. Technical Support to EU Strategy on Invasive Species (IAS)_Assessment of the Impacts of IAS in Europe and the EU; Final Module Report for the European Commission; Institute for European Environmental Policy (IEEP): Brussels, Belgium, 2008; 43p, Available online: htpps: / / ec.europa.eu/environment/ nature/invasivealien/docs/Kettunen2009_IAS_Task\%201.pdf (accessed on 20 January 2021).

78. Kettunen, M.; Bassi, S.; Gantioler, S.; Ten Brink, P. Assessing Socio-Economic Benefits of Natura 2000-A Toolkit for Practitioners (September 2009 Edition). Output of the European Commission Project Financing Natura 2000: Cost Estimate and Benefits of Natura 2000 (Contract No.: 070307/2007/484403/MAR/B2); Institute for European Environmental Policy (IEEP): Brussels, Belgium, 2009; 191p. 
79. Kettunen, M.; Berghofer, A.; Bouamrane, A.M.; Brunner, A.; Chape, S.; Conner, N.; Dudley, N.; Ervin, J.; Gidda, S.B.; Morling, P.; et al. Recognising the value of protected areas. In TEEB in National Policy-The Economics of Ecosystems and Biodiversity in National and International Policy Making; Ten Brink, P., Ed.; IEEP: Brussels, Belgium; Earthscan: London, UK, 2011.

80. Stolton, S.; Dudley, N.; Randall, J. Natural Security: Protected Areas and Hazard Mitigation; WWF International: Gland, Switzerland, 2008.

81. Gantioler, S.; Rayment, M.; Bassi, S.; Kettunen, M.; McConville, A.; Landgrebe, R.; Gerdes, H.; ten Brink, P. Costs and SocioEconomic Benefits Associated with the Natura 2000 Network; Final Report to the European Commission, DG Environment on Contract ENV.B.2/SER/2008/0038; Institute for European Environmental Policy/GHK/Ecologic: Brussels, Belgium, 2010.

82. Mulongoy, K.J.; Gidda, S.B. The Value of Nature: Ecological, Economic, Cultural and Social Benefits of Protected Areas; Secretariat of the Convention on Biological Diversity: Montreal, QC, Canada, 2008.

83. European Union. The Economic benefits of the Natura 2000 Network; European Union: Luxembourg, 2013; Available online: https:/ / ec.europa.eu/environment/nature/natura2000/financing/docs/ENV-12-018_LR_Final1.pdf (accessed on 20 January 2021).

84. BIO Intelligence Service. Estimating Economic Value of the Benefits Provided by the Tourism/Recreation and Employment Supported by Natura 2000, Final Report Prepared for European Commission-DG Environment. 2011. Available online: http:/ / ec.europa.eu/environment/nature/natura2000/financing/docs/Estimating_economic_value.pdf (accessed on 20 January 2021).

85. Balmford, A.; Rodrigues, A.S.L.; Walpole, M.; ten Brink, P.; Kettunen, M.; Braat, L.; de Groot, R. The Economics of Biodiversity and Ecosystems: Scoping the Science, European Commission (Contract: ENV/070307/2007/486089/ETU/B2), Cambridge. 2008. Available online: http:/ / ec.europa.eu/environment/nature/biodiversity/economics/pdf/scoping_science_report.pdf (accessed on 21 March 2021).

86. Gallai, N.; Salles, J.M.; Settele, J.; Vaissiere, B.E. Economic valuation of the vulnerability of world agriculture confronted with pollinator decline. Ecol. Econ. 2009, 68, 810-821. [CrossRef]

87. Lower Danube Green Corridor: Floodplain Restoration for Flood Protection-Climate-aDAPT. 2014. Available online: http: / / climate-adapt.eea.europa.eu/metadata/case-studies/lower-danube-green-corridor-floodplain-restoration-for-floodprotection (accessed on 21 March 2021).

88. Homepage of the Project "Theiss-Management of Floodplains on the Tisza". Available online: http://www.tiszalife.hu/en/ life_eredm.htm (accessed on 5 April 2021).

89. Jurkiewicz, J. The Secret Garden. 2014. Available online: http://www.kopernik.org.pl/en/exhibitions/ogrod-na-dachu/rosliny/ (accessed on 10 April 2021).

90. Pabian, O.; Jaroszewicz, B. Assessing Socio-Economic Benefits of Natura 2000-A Case Study on the Ecosystem Service Provided by Białowieża Forest. Output of the Project Financing Natura 2000: Cost Estimate and Benefits of Natura 2000, (Contract No.: 070307/2007/484403/MAR/B2). 2009. 69p. Available online: http:/ /ec.europa.eu/environment/nature/natura2000/financing/ docs/bialowiaza_case_study.pdf (accessed on 21 March 2021).

91. Kazakova, Y.; Pop, E. Assessing Socio-Economic Benefits of Natura 2000—A Case Study on the Ecosystem Services Provided by Oaş-Gutâi Plateau and Igniş Site, Maramures, Romania. Output of the Project Financing Natura 2000: Cost Estimate and Benefits of Natura 2000, (Contract No: 070307/2007/484403/MAR/B2). 2009, 22p. + Annexes. Available online: http: / /ec.europa.eu/environment/nature/natura2000/financing/docs/maramures_case_study.pdf (accessed on 21 March 2021).

92. Fundatia ADEPT Transilvania. Târnava Mare SCI. Saving Transylvania's Important Pastoral Ecosystems. Salvarea Ecosistemelor Pastorale Importante ale Transilvaniei. STIPA 2010-2013. 2013. Available online: http:/ / www.fundatia-adept.org/bin/file/life/ Life_STIPA-ADEPT_report-KSrev-A4Reading_EN-web.pdf (accessed on 21 March 2021).

93. Ten Brink, P.; Mutafoglu, K.; Schweitzer, J.P.; Kettunen, M.; Twigger-Ross, C.; Baker, J.; Kuipers, Y.; Emonts, M.; Tyrväinen, L.; Hujala, T.; et al. The Health and Social Benefits of Nature and Biodiversity Protection; A Report for the European Commission (ENV.B.3/ETU/2014/0039); Institute for European Environmental Policy: London, UK; Brussels, Belgium, 2016; Available online: http:/ /ieep.eu/assets/2093/Health_and_Social_Benefits_of_Nature_-_Final_Report_Main_sent.pdf (accessed on 21 March 2021).

94. Pearce, D.W.; Howarth, A. Technical Report on Methodology: Cost Benefit Analysis and Policy Responses. RIVM Report 481505020. 2020. Available online: http:/ / www.rivm.nl/bibliotheek/rapporten/481505020.pdf (accessed on 10 March 2019).

95. Pearce, D.W. Economic Values and the Natural World; MIT Press: Cambridge, MA, USA, 1993.

96. Costanza, R.; d'Arge, R.; de Groot, R.; Farber, S.; Grasso, M.; Hannon, B.; Limburg, K.; Naeem, S.; O’Neill, R.V.; Paruelo, J.; et al. The value of the world's ecosystem services and natural capital. Nature 1997, 387, 253-260. [CrossRef]

97. Bottero, M. The economic value of landscape: An application for a rural area in Northern Italy. In Landscape Planning and Rural Development; Rega, C., Ed.; Springer: Berlin, Germany, 2014; pp. 89-104. [CrossRef]

98. Bottero, M. A multi-methodological approach for assessing sustainability of urban projects. Manag. Environ. Qual. Int. J. 2015, 26, 138-154. [CrossRef]

99. Chen, B.; Qi, X. Protest response and contingent valuation of an urban forest park in Fuzhou City, China. Urban For. Urban Green. 2018, 29, 68-76. [CrossRef]

100. Maltese, I.; Mariotti, I.; Oppio, A.; Boscacci, F. Assessing the benefits of slow mobility connecting a cultural heritage. J. Cult. Herit. 2017, 26, 153-159. [CrossRef] 
101. Oppio, A.; Bottero, M.; Ferretti, V. Designing adaptive reuse strategies for cultural heritage with choice experiments. In Appraisal: From Theory to Practice; Stanghellini, S., Morano, P., Bottero, M., Oppio, A., Eds.; Springer: Cham, Switzerland, 2017 ; pp. $303-315$. [CrossRef]

102. Berta, M.; Bottero, M.; Ferretti, V. A mixed methods approach for the integration of urban design and economic evaluation: Industrial heritage and urban regeneration in China. Environ. Plan. B Plan. Des. 2016, 45, 1-25. [CrossRef]

103. Mitchell, R.C.; Carson, R.T. Using Surveys to Value Public Goods: The Contingent Valuation Method; Resources for the Future: Washington, DC, USA, 1989.

104. Ciriacy-Wantrup, S.V. Capital returns from soil conservation practices. Am. J. Agric. Econ. 1947, 29 Pt 2, 1181-1196. [CrossRef]

105. Stander, L.; Theodore, L. Environmental Regulatory Calculations Handbook; John Wiley \& Sons, Inc.: Hoboken, NJ, USA, 2006. [CrossRef]

106. Gramling, R.; Freudenburg, W.R. The Exxon Valdez oil spill in the context of US petroleum politics. Organ. Environ. 1992, 6, 175-196. [CrossRef]

107. Arrow, K.; Solow, R.; Portney, P.R.; Leamer, E.E.; Radner, R.; Schuman, H. Report of the NOAA Panel on Contingent Valuation. Fed. Regist. 1993, 58, 4601-4614.

108. Stellin, G.; Rosato, P. La Valutazione Economica dei Beni Ambientali: Metodologia e Casi di Studio; Cittàstudi: Torino, Italy, 1998.

109. Halkos, G.; Leonti, A.; Sardianou, E. Assessing the Preservation of Parks and Natural Protected Areas: A Review of Contingent Valuation Studies. Sustainability 2020, 2, 4784. [CrossRef]

110. Pearce, D.W.; Turner, R.K. Economics of Natural Resources and the Environment; Johns Hopkins University Press: Baltimore, MD, USA, 1990. [CrossRef]

111. Bateman, I.J.; Carson, R.T.; Day, B.; Hanemann, M.; Hanley, N.; Hett, T.; Jones-Lee, M.; Loomes, G.; Mourato, S.; Ozdemiroglu, E.; et al. Economic Valuation with Stated Preference Techniques: A Manual; Edward Elgar, Ltd.: Cheltenham, UK, $2002 ;$ ISBN 1840649194.

112. Tempesta, T.; Marangon, F. Stima del valore economico totale dei paesaggi forestali italiani tramite valutazione contingente. Genio Rurale. 2004, 11, 32-45.

113. Giannelli, A.; Giuffrida, S.; Trovato, M.R. Madrid Rio Park. Symbolic Values and Contingent Valuation, Valori e Valutazioni; Issue 21; E-Flow Dei Tipografia del Genio Civile: Rome, Italy, 2018; ISSN 20362404.

114. Clawson, M. Methods of Measuring the Demand for and Value of Outdoor Recreation; Reprint No. 10; Resources for the Future: Washington, DC, USA, 1959.

115. Hotelling, H. Letter. In An Economic Study of the Monetary Evaluation of Recreation in the National Parks; National Park Service: Washington, DC, USA, 1949.

116. Carr, L.; Mendelsohn, R. Valuing coral reefs: A travel cost analysis of the Great Barrier Reef. Ambio 2003, 32, 353-357. [CrossRef] [PubMed]

117. Randall, A. A difficulty with the Travel Cost Method. Land Econ. 1994, 70, 88-96. [CrossRef]

118. Bedate, A.; Herrero, L.C.; Sanz, J.A. Economic valuation of the cultural heritage: Application to four case studies in Spain. J. Cult. Herit. 2004, 5, 101-111. [CrossRef]

119. Torres-Ortega, S.; Pérez-Álvarez, R.R.; Díaz-Simal, P.; de Luis-Ruiz, J.M.; Piña-García, F. Economic Valuation of Cultural Heritage: Application of Travel Cost Method to the National Museum and Research Center of Altamira. Sustainability 2018, $10,2550$. [CrossRef]

120. Feather, P.; Shaw, W.D. Estimating the Cost of Leisure Time for Recreation Demand Models. J. Environ. Econ. Manag. 1999, 38, 49-65. [CrossRef]

121. Tempesta, T. Appunti di Estimo Ambientale e Rurale; CLEUP-Cooperativa Libraria Editrice; Università di Padova: Padova, Italy, 2011.

122. Parsons, G.R. The Travel Cost Model. In A Primer on Nonmarket Valuation; Champ, P.A., Boyle, K., Brown, T.C., Eds.; Springer: New York, NY, USA, 2003. [CrossRef]

123. Bottarelli, M.; Gabrielli, L. Payback period for a ground source heat pump system. Int. J. Heat Technol. 2011, 29, 145-150.

124. Gabrielli, L.; Bottarelli, M. Financial and economic analysis for ground-coupled heat pumps using shallow ground heat exchangers. Sustain. Cities Soc. 2016, 20, 71-80. [CrossRef]

125. Nocera, F.; Giuffrida, S.; Trovato, M.R.; Gagliano, A. Energy and New Economic Approach for Nearly Zero Energy Hotels. Entropy 2019, 21, 639. [CrossRef] [PubMed]

126. Giuffrida, S.; Gagliano, F.; Nocera, F.; Trovato, M.R. Landscape assessment and Economic Accounting in wind farm Programming: Two Cases in Sicily. Land 2018, 7, 120. [CrossRef]

127. Bottero, M.; Comino, E.; Dell'Anna, F.; Dominici, L.; Rosso, M. Strategic Assessment and Economic Evaluation: The Case Study of Yanzhou Island (China). Sustainability 2019, 11, 1076. [CrossRef]

128. Nesticò, A.; Guarini, M.R.; Morano, P.; Sica, F. An economic analysis algorithm for urban forestry projects. Sustainability 2019, 11, 314. [CrossRef]

129. Giuffrida, S.; Carocci, C.; Circo, C.; Giuffrè, M.; Trovato, M.R.; Ventura, V. Axiological strategies in the old towns seismic vulnerability mitigation planning. Valori Valutazioni 2020, 2020, 99-106.

130. Napoli, G.; Giuffrida, S.; Trovato, M.R.; Valenti, A. Cap Rate as the Interpretative Variable of the Urban Real Estate Capital Asset: A Comparison of Different Sub-Market Definitions in Palermo, Italy. Buildings 2017, 7, 80. [CrossRef] 
131. Giuffrida, S.; Ventura, V.; Trovato, M.R.; Napoli, G. Axiology of the historical city and the cap rate the case of the old town of Ragusa superior. Valori Valutazioni 2017, 18, 41-55.

132. Giuffrida, S.; Casamassima, G.; Trovato, M.R. Le norme EMAS-ISO nella valutazione della qualità del servizio idrico integrato. Aestimum 2017, 70, 109-134. [CrossRef]

133. Napoli, G.; Giuffrida, S.; Trovato, M.R. Efficiency versus fairness in the management of public housing assets in Palermo (Italy). Sustainability 2019, 11, 1199. [CrossRef]

134. Trovato, M.R.; Nocera, F.; Giuffrida, S. Life-Cycle Assessment and Monetary Measurements for the Carbon Footprint Reduction of Public Buildings. Sustainability 2020, 12, 3460. [CrossRef]

135. Giuffrida, S.; Trovato, M.R.; Circo, C.; Ventura, V.; Giuffrè, M.; Macca, V. Seismic Vulnerability and Old Towns. A Cost-Based Programming Model. Geosciences 2019, 9, 427. [CrossRef]

136. Giuffrida, S.; Ventura, V.; Nocera, F.; Trovato, M.R.; Gagliano, F. Technological, Axiological and Praxeological Coordination in the Energy-Environmental Equalization of the Strategic Old Town Renovation Programs. In Values and Functions for Future Cities; Mondini, G., Oppio, A., Stanghellini, S., Bottero, M., Abastante, F., Eds.; Part of Green Energy and Technology; Springer: Cham, Switzerland, 2020; pp. 425-446. [CrossRef]

137. Trovato, M.R.; Giuffrida, S. The Monetary Measurement of Flood Damage and the Valuation of the Proactive Policies in Sicily. Geosciences 2018, 8, 141. [CrossRef]

138. Trovato, M.R.; Giuffrida, S. The Protection of Territory from the Perspective of the Intergenerational Equity. In Integrated Evaluation for the Management of Contemporary Cities; Mondini, G., Fattinnanzi, E., Oppio, A., Bottero, M., Stanghellini, S., Eds.; SIEV 2016. Green Energy and Technology; Springer: Cham, Switzerland, 2018; pp. 469-485. [CrossRef]

139. Trovato, M.R. A multi-criteria approach to support the retraining plan of the Biancavilla's old town. In Proceedings of the 3rd International New Metropolitan Perspectives. Local Knowledge and Innovation Dynamics towards Territory Attractiveness through the Implementation of Horizon/Europe2020/Agenda2030, 2018, Reggio Calabria, Italy, 22-25 May 2018; Bevilacqua, C., Calabro, F., Della Spina, L., Eds.; Smart Innovation, Systems and Technologies. Springer: Cham, Switzerland, 2019; Volume 101, pp. 434-441. [CrossRef]

140. Hicks, J.R. Value and Capital; Clarendon Press: Oxford, UK, 1946.

141. Giuffrida, S.; Gagliano, F.; Giannitrapani, E.; Marisca, C.; Napoli, G.; Trovato, M.R. Promoting Research and Landscape Experience in the Management of the Archaeological Networks. A Project-Valuation Experiment in Italy. Sustainability 2020, 12, 4022. [CrossRef]

142. Open data Regione Sicilia - Aree protette e Rete Natura 2000. Available online: https://dati.regione.sicilia.it/dataset/areeprotette-e-rete-natura-2000 (accessed on 2 March 2019).

143. Ministero della transizione ecologica. Available online: https://ftp.minambiente.it/pnm/Natura2000/TrasmissioneCE_aprile202 0/schede_mappe/Sicilia/ZSC_schede/Site_ITA070004.pdf (accessed on 2 March 2019).

144. Rete Natura 2000 Sicilia. Available online: https:/ / www.lasiciliainrete.it/elenco-sic-zsc-zps-regione-siciliana/ (accessed on 2 March 2019).

145. La Timpa. La Riserva Naturale Orientata. Available online: https://www.riservalatimpa.it/it/la-riserva/ (accessed on 2 March 2019).

146. Dipartimento Regionale Agenzia Foreste Demaniali. Piano di Gestione. Ambito Territoriale "Timpa di Acireale"; Dipartimento Regionale Agenzia Foreste Demaniali: Sicily, Italy, 2009.

147. Song, X.H.; Cho, T.D.; Lang, X.X.; Piao, Y.J. Influencing the willingness to pay for urban park service functions. J. Environ. Sci. Int. 2013, 22, 1279-1285. [CrossRef]

148. Venkatachalam, L. The contingent valuation method: A review. Environ. Impact Assess. Rev. 2004, 24, 89-124. [CrossRef]

149. Grazhdani, D. Estimating residents' willing to pay using contingent valuation for ecological restoration and recreational benefits of AL-Prespa protected area in Albania. J. Food Agric. Environ. 2014, 12, 365-370.

150. Martin-Lopez, B.; Montes, C.; Benayas, J. Influence of user characteristics on valuation of ecosystem services in Donana natural protected area (south-west Spain). Environ. Conserv. 2007, 34, 215-224. [CrossRef]

151. Latinopoulos, D.; Mallios, Z.; Latinopoulos, P. Valuing the benefits of an urban park project: A contingent valuation study in Thessaloniki, Greece. Land Use Policy 2016, 55, 130-141. [CrossRef]

152. Majumdar, S.; Deng, J.; Zhang, Y.; Pierskalla, C. Using contingent valuation to estimate the willingness of tourists to pay for urban forests: A study in Savannah, Georgia. Urban For. Urban Green. 2011, 10, 275-280. [CrossRef]

153. European Commission. Guide to Cost-Benefit Analysis of Investment Projects 2007-2013. 2008. Available online: https:/ / ec.europa.eu/regional_policy/en/information/publications/evaluations-guidance-documents /2008/guide-tocost-benefit-analysis-of-investment-projects (accessed on 2 March 2019).

154. Maselli, G.; Nesticò, A.A. L'analisi costi-benefici per progetti in campo ambientale. La scelta del saggio di sconto. Laborest 2020, 20,99-104.

155. Global Petrol Price. Available online: https://www.globalpetrolprices.com (accessed on 2 March 2019).

156. Quattoruote. Available online: https:/ / www.quattroruote.it (accessed on 2 March 2019).

157. Thapa, A.K. Recreational demand for Fewa lake: An application of travel cost method. Econ. Lit. 2013, 11, 54-59. [CrossRef] 
158. Driml, S. Travel cost analysis of recreation value in the wet tropics world heritage area. Econ. Anal. Policy 2002, 32, 11-26. [CrossRef]

159. Naselli, F.; Trovato, M.R.; Castello, G. An evaluation model for the actions in supporting of the environmental and landscaping rehabilitation of the Pasquasia's site mining (EN). In Computational Science and Its Applications-ICCSA 2014, Proceedings of the 14th International Conference, ICCSA 2014, Guimarães, Portugal, 30 June-3 July 2014; Murgante, B., Misra, S., Rocha, A.M.A.C., Torre, C.M., Rocha, J.G., Falcão, M.I., Taniar, D., Apduhan, B.O., Gervasi, O., Eds.; Springer International Publishing: Cham, Switzerland, 2014; pp. 26-41. [CrossRef]

160. De la Cruz, A.; Benedicto, J. Assessing Socioeconomic Benefits of Natura 2000—A Case Study on the Ecosystem Service Provided by SPA Pico Da Vara/Ribeira DO Guilherme. Output of the Project Financing Natura 2000: Cost Estimate and Benefits of Natura 2000. (Contract No.: 070307/2007/484403/MAR/B2). 2009. Available online: http:/ /ec.europa.eu/environment/nature/natura2 000 / financing/docs/azores_case_study.pdf (accessed on 20 January 2021).

161. Butcher Partners Limited. Economic Benefits of Water in Te Papanui Conservation Park; Inception Report; Butcher Partners Limited: Christchurch, New Zealand, 2006.

162. Luhmann, N. Sistemi Sociali. Fondamenti di Una Teoria Generale; Il Mulino: Bologna, Italy, 1990.

163. Szetey, K.; Moallemi, E.A.; Ashton, E.; Butcher, M.; Sprunt, B.; Bryan, B.A. Co-creating local socioeconomic pathways for achieving the sustainable development goals. Sustain. Sci. 2021, 1-18. [CrossRef]

164. Tan, D.T.; Siri, J.G.; Gong, Y.; Ong, B.; Lim, S.C.; MacGillivray, B.H.; Marsden, T. Systems approaches for localising the SDGs: Co-production of place-based case studies. Glob. Health 2019, 15, 1-10. [CrossRef]

165. Lachmund, J. Greening Berlin: The Co-Production of Science, Politics, and Urban Nature; MIT Press: Cambridge, MA, USA, 2013; Available online: http:/ / public.eblib.com/choice/publicfullrecord.aspx?p=3339559 (accessed on 20 January 2021).

166. Guimarães, M.H.; Ballé-Béganton, J.; Bailly, D.; Newton, A.; Boski, T.; Dentinho, T. Transdisciplinary conceptual modeling of a social-ecological system-A case study application in Terceira Island, Azores. Ecosyst. Serv. 2013, 3, 22-31. [CrossRef]

167. De Oliveira, J.A.P.; Doll, C.N.H.; Siri, J.; Dreyfus, M.; Farzaneh, H.; Capon, A. Urban governance and the systems approaches to health-environment co-benefits in cities. Cad. Saúde Pública 2015, 31, 25-38. [CrossRef]

168. Eagles, P.; Hillel, O. Improving Protected Area Finance through Tourism in Protected Areas, in SCBD (Secretariat of the Convention on Biological Diversity) Protected Areas in Today's World: Their Values and Benefits for the Welfare of the Planet, CBD Technical Series No 36, CBD, Montreal. 2008. Available online: http:/ / www.cbd.int/doc/publications/cbd-ts-36-en.pdf (accessed on 30 March 2021).

169. Shrestha, R.K.; Stein, T.V.; Clark, J. Valuing nature-based recreation in public natural areas of the Apalachicola river region, Florida. J. Environ. Manag. 2007, 85, 977-985. [CrossRef]

170. Lee, A.C.K.; Maheswaran, R. The health benefits of urban green spaces: A review of the evidence. J. Public Health 2011, 33, 212-222. [CrossRef]

171. Kim, C.W.; Phipps, T.; Anselin, L. Measuring the benefits of air quality improvement: A spatial hedonic approach. J. Environ. Econ. Manag. 2003, 45, 24-39. [CrossRef]

172. Negra, C.; Remans, R.; Attwood, S.; Sarah Jones, S.; Werneck, F.; Smith, A. Sustainable agri-food investments require multi-sector co-development of decision tools. Ecol. Indic. 2020, 110, 105851. [CrossRef]

173. Le Tran, Y.; Siry, J.P.; Bowker, J.M.; Poudyal, N.C. Atlanta households' willingness to increase urban forests to mitigate climate change. Urban For. Urban Green. 2017, 22, 84-92. [CrossRef]

174. Kabisch, N.; Qureshi, S.; Haase, D. Human-Environment interactions in urban green spaces-A systematic review of contemporary issues and prospects for future research. Environ. Impact Assess. Rev. 2015, 50, 25-34. [CrossRef]

175. Trovato, M.R.; Giuffrida, S. The choice problem of the urban performances to support the Pachino's redevelopment plan. Int. J. Bus. Intell. Data Min. 2014, 9, 330-355. [CrossRef]

176. Trovato, M.R.; Giuffrida, S. A DSS to Assess and Manage the Urban Performances in the Regeneration Plan: The Case Study of Pachino. In Computational Science and Its Applications-ICCSA 2014, Proceedings of the 14th International Conference, ICCSA 2014, Guimarães, Portugal, 30 June-3 July 2014; Murgante, B., Misra, S., Rocha, A.M.A.C., Torre, C.M., Rocha, J.G., Falcão, M.I., Taniar, D., Apduhan, B.O., Gervasi, O., Eds.; Springer International Publishing: Cham, Switzerland, 2014; Volume 8581, pp. 224-239. [CrossRef]

177. Pearson, L.J.; Tisdell, C.; Lisle, A.T. The impact of Noosa National Park on surrounding property values: An application of the hedonic price method. Econ. Anal. Policy 2002, 32, 155-171. [CrossRef]

178. Salvo, F.; Romita, T.; De Ruggiero, M.; Tavano, D. Residential tourism and real estate appraisal: Turismo residenziale e valutazione immobiliare. Valori Valutazioni 2020, 25, 53-58.

179. Gabrielli, L.; Giuffrida, S.; Trovato, M.R. From Surface to Core: A Multi-Layer Approach for the Real Estate Market Analysis of a Central Area in Catania. In Computational Science and Its Applications-ICCSA 2015, Proceedings of the 15th International Conference, ICCSA 2015, Banff, AB, Canada, 22-25 June 2015; Gervasi, O., Rocha, A.M.A.C., Murgante, B., Taniar, D., Apduhan, B.O., Gavrilova, M.L., Misra, S., Torre, C., Eds.; Lecture Notes in Computer Science; Springer: Cham, Switzerland, 2015; Volume 9157, pp. 284-300. [CrossRef] 
180. Gabrielli, L.; Giuffrida, S.; Trovato, M.R. Functions and Perspectives of Public Real Estate in the Urban Policies: The Sustainable Development Plan of Syracuse. In Computational Science and Its Applications-ICCSA 2016, Proceedings of the 16th International Conference, ICCSA 2016, Beijing, China, 4-7 July 2016; Gervasi, O., Murgante, B., Misra, S., Rocha, A.M.A.C., Torre, C.M., Taniar, D., Apduhan, B.O., Stankova, E., Wang, S., Eds.; Lecture Notes in Computer Science; Springer: Cham, Switzerland, 2016; pp. 13-28. [CrossRef]

181. Gabrielli, L.; Giuffrida, S.; Trovato, M.R. Gaps and Overlaps of Urban Housing Sub-market: Hard Clustering and Fuzzy Clustering Approaches. In Appraisal: From Theory to Practice; Stanghellini, S., Morano, P., Bottero, M., Oppio, A., Eds.; Green Energy and Technology; Springer: Cham, Switzerland, 2017; pp. 203-219. [CrossRef] 